This item was submitted to Loughborough's Research Repository by the author.

Items in Figshare are protected by copyright, with all rights reserved, unless otherwise indicated.

\title{
Exploration of associations between the FTO rs9939609 genotype, fasting and postprandial appetite-related hormones and perceived appetite in healthy men and women
}

\section{PLEASE CITE THE PUBLISHED VERSION}

https://doi.org/10.1016/j.appet.2019.104368

\section{PUBLISHER}

Elsevier

\section{VERSION}

AM (Accepted Manuscript)

\section{PUBLISHER STATEMENT}

This paper was accepted for publication in the journal Appetite and the definitive published version is available at https://doi.org/10.1016/j.appet.2019.104368.

\section{LICENCE}

CC BY-NC-ND 4.0

\section{REPOSITORY RECORD}

Goltz, Fernanda R., Alice Thackray, Veronica Varela-Mato, James King, James L. Dorling, Monika Dowejko, Sarabjit Mastana, Julie Thompson, Greg Atkinson, and David Stensel. 2019. "Exploration of Associations Between the FTO Rs9939609 Genotype, Fasting and Postprandial Appetite-related Hormones and Perceived Appetite in Healthy Men and Women". figshare. https://hdl.handle.net/2134/38308. 
Exploration of associations between the FTO rs9939609 genotype, fasting and postprandial appetite-related hormones and perceived appetite in healthy men and women

4

Fernanda R. Goltz ${ }^{1,2}$, Alice E. Thackray ${ }^{1,2}$, Veronica Varela-Mato ${ }^{1}$, James A. King ${ }^{1,2}$, James L. Dorling ${ }^{3}$, Monika Dowejko ${ }^{1}$, Sarabjit Mastana ${ }^{1}$, Julie Thompson ${ }^{1,2}$, Greg Atkinson ${ }^{4}$, David J. Stensel ${ }^{1,2}$

7

$8{ }^{1}$ National Centre for Sport and Exercise Medicine, School of Sport, Exercise and Health 9 Sciences, Loughborough University, Loughborough, United Kingdom.

$10{ }^{2}$ University Hospitals of Leicester NHS Trust, Infirmary Square, Leicester, United Kingdom.

113 Ingestive Behavior Laboratory, Pennington Biomedical Research Center, Baton Rouge, 12 United States.

$13{ }^{4}$ School of Health and Social Care, Teesside University, Middlesbrough, United Kingdom. 14

15 Corresponding author:

16 Professor David Stensel

17 School of Sport, Exercise and Health Sciences

18 Loughborough University

19 Leicestershire

20 LE11 3TU

21 United Kingdom

22 Phone: +44(0)1509 226344, Fax:+44(0)1509 226301, E-mail: D.J.Stensel@lboro.ac.uk 23

Declarations of interest: None. 
27 Background: The fat mass and obesity-associated gene (FTO) rs9939609 A-allele has been 28 associated with obesity risk. Although the exact mechanisms involved remain unknown, the FTO 29 rs9939609 A-allele has been associated with an impaired postprandial suppression of appetite.

30 Objectives: To explore the influence of FTO rs9939609 genotype on fasting and postprandial 31 appetite-related hormones and perceived appetite in a heterogeneous sample of men and women.

32 Design: 112 healthy men and women aged 18-50-years-old completed three laboratory visits for 33 the assessment of FTO rs9939609 genotype, body composition, aerobic fitness, resting 34 metabolic rate, visceral adipose tissue, liver fat, fasting leptin, and fasting and postprandial 35 acylated ghrelin, total PYY, insulin, glucose and perceived appetite. Participants wore 36 accelerometers for seven consecutive days for the assessment of physical activity and sedentary 37 behaviour. Multivariable general linear models quantified differences between FTO rs9939609 38 groups for fasting and postprandial appetite outcomes, with and without the addition of a priori 39 selected physiological and behavioural covariates. Sex-specific univariable Pearson's correlation 40 coefficients were quantified between the appetite-related outcomes and individual characteristics. 41 Results: 95\% confidence intervals for mean differences between FTO rs9939609 groups 42 overlapped zero in unadjusted and adjusted general linear models for all fasting $(P \geq 0.28)$ and 43 postprandial $(P \geq 0.19)$ appetite-related outcomes. Eta $^{2}$ values for explained variance attributable 44 to FTO rs 9939609 were $<5 \%$ for all outcomes. An exploratory correlation matrix indicated that 45 associations between fasting and postprandial acylated ghrelin, total PYY and general or 46 abdominal adiposity were also small $(\mathrm{r}=-0.23$ to $0.15, P \geq 0.09)$. Fasting leptin, glucose and 47 insulin and postprandial insulin concentrations were associated with adiposity outcomes $(\mathrm{r}=$ 480.29 to $0.81, P \leq 0.033)$. Conclusions: Associations between the FTO rs9939609 genotype and 49 fasting or postprandial appetite-related outcomes were weak in healthy men and women. 50

51 Keywords: FTO, appetite, ghrelin, PYY, hunger. 
53 The scientific understanding of appetite control has increased considerably in recent decades, 54 which has been helpful in elucidating the complex nature of energy balance and weight control. 55 Central components of the homeostatic control of appetite comprise signals from adipose tissue 56 and peptide hormones secreted from the digestive tract, which act acutely and/or chronically on central neural pathways to influence hunger, satiety and subsequent energy intake (MacLean et al. 2017). These signals and hormones include the tonic signals leptin and insulin that regulate long-term changes in energy balance and adiposity status, as well as a variety of episodic gut signals, which mediate hunger and satiety on a meal-by-meal basis (Blundell et al. 2008, 2015a; MacLean et al. 2017). Notable among the episodic mediators of appetite and energy intake are acylated ghrelin and peptide YY (PYY) which exert orexigenic and anorexigenic effects, respectively, to facilitate meal initiation and termination (Neary and Batterham, 2009). Over the last 16 years, our laboratory has measured circulating concentrations of appetite-related hormones in response to meal ingestion in many studies. A consistent observation from this body of work is the degree of variability in responses observed between participants studied under identical conditions. Furthermore, using the "gold standard" replicated crossover study design (Atkinson and Batterham, 2015; Senn, 2016), we have demonstrated recently the presence of true interindividual heterogeneity in appetite perceptions and circulating concentrations of acylated ghrelin, total PYY, insulin and glucose in response to a standardised meal, over and above any random within-subject variability and measurement error (Goltz et al. 2019). Similar findings were also observed in acylated ghrelin, total PYY and perceived appetite responses to replicated single bouts of aerobic exercise (Goltz et al. 2018).

The factors responsible for interindividual variability in appetite-related hormone concentrations are not fully understood, but it is plausible that differences in individual characteristics and behaviours may contribute to the variability observed. In this regard, the fat mass and obesityassociated gene (FTO) has been associated with obesity risk, with individuals homozygous for

78 the A allele (AA) of FTO rs9939609 having a 1.7-fold higher obesity risk than individuals homozygous for the T allele (TT) (Frayling et al. 2007). Although the exact mechanisms through which FTO rs9939609 influences fat mass accumulation remain unknown, it has been suggested

81 that it exerts its effect on food intake rather than on energy expenditure (Speakman et al. 2008).

82 Furthermore, rs9939609 AA individuals have been shown to exhibit an attenuated postprandial 83 suppression of hunger and acylated ghrelin compared with TT individuals, which may 
predispose AA individuals to higher energy intake and, consequently, higher fat mass (Karra et al. 2013). However, the study by Karra and colleagues was performed in young healthy weight males and it is not known whether this influence of the FTO rs9939609 gene on postprandial appetite regulation is observed in a heterogenous sample of men and women.

Beyond genetic influence, it has been speculated that other individual factors may affect appetite regulation. Data from previous studies have indicated that women exhibit higher fasting concentrations of acylated ghrelin than men in those who were lean (Alajmi et al. 2016; Douglas et al. 2017) and in those who were overweight/obese (Douglas et al. 2017). Furthermore, an inverse relationship between general adiposity levels and fasting ghrelin levels has been suggested in study samples including individuals who were lean and individuals who were obese, possibly because of elevated insulin or leptin levels (Tschöp et al. 2001; Shiiya et al. 2002; Sondergaard et al. 2009). Individuals who are obese also exhibit a reduced postprandial suppression of ghrelin (Le Roux et al. 2005) and blunted postprandial increases in PYY (Le Roux et al. 2006). Limited evidence has also suggested an inverse association between visceral adipose tissue and fasting ghrelin levels in women who were lean and women who were obese, likely caused by substances secreted by visceral adipocytes, such as TNF $\alpha$ and leptin (Sondergaard et al. 2009). Moreover, fat-free mass, as the largest contributor to resting metabolic rate, has been identified as a key driver of appetite and energy intake in individuals who were lean and in individuals who were obese (Blundell et al. 2015b). In a systematic review including studies in individuals with normal weight, overweight or obesity, physical activity has also been suggested to alter the sensitivity of the appetite control system by enhancing meal-induced satiety which may facilitate energy balance over the long term (Beaulieu et al. 2016). Together, these findings highlight the importance of investigating the effect of the FTO rs9939609 gene on appetite parameters in a sample of males and females with a wide range of age, adiposity and physical activity levels, including physiological and behavioural characteristics as covariates in the analyses.

The primary aim of this study was to use objective assessment methods in order to explore the influence of the FTO rs9939609 genotype on fasting and postprandial appetite-related hormones and perceived appetite in a sample of healthy men and women. The secondary aim was to explore potential associations between fasting and postprandial appetite outcomes and physiological and behavioural characteristics. 


\section{METHODS}

\section{Participants}

118 With the approval of the University Ethics Advisory Sub-Committee, a total of 121 participants 119 (57 men, 64 women) aged 18 to 50 years provided written informed consent before taking part 120 in the study. All participants were deemed to be stable in their body mass $(\leq 3 \mathrm{~kg}$ change in the 121 previous 3 months), non-smokers, habitual breakfast eaters, had no history of cardiovascular or 122 metabolic disease, and were not dieting or taking any medications known to influence the 123 outcome measures. Female participants were premenopausal and postmenopausal and not 124 pregnant. Nine participants withdrew from the study before completing all study measurements 125 due to time constraints. Therefore, data are presented for 112 participants (56 men, 56 women) 126 in this manuscript. The study sample self-reported ethnicity distribution was as follows: $93 \%$ 127 white Europeans, 6\% Asians and 1\% black.

\section{$128 \quad$ Visit 1: Preliminary testing}

129 Participants attended the laboratory for a preliminary visit to confirm eligibility, and to undergo 130 familiarisation, anthropometric measurements and determination of peak oxygen uptake $\left(\mathrm{V}_{2}\right.$ 131 peak). The eligibility assessment included screening questionnaires to assess health status and 132 food preferences and/or restrictions. Stature was measured to the nearest $0.1 \mathrm{~cm}$ and body mass 133 to the nearest $0.1 \mathrm{~kg}$ using an electronic measuring station (Seca, Hamburg, Germany), and body 134 mass index (BMI) was calculated. The sum of three skinfolds (chest, abdomen and thigh for men, 135 and triceps, suprailiac and thigh for women) was used to estimate body density (Jackson and 136 Pollock 1978, 1980) and body fat percentage (Siri, 1961). All skinfold measurements were 137 performed by the same experienced examiner throughout the study. Waist circumference was 138 measured as the narrowest point between the lower rib margin and the iliac crest.

139 Participants were familiarised with walking and running on the treadmill (Technogym Excite 140 Med, Cesena, Italy) before completing an incremental uphill treadmill protocol to determine $\dot{\mathrm{V}}_{2}$ 141 peak. The participants ran at a fixed individualised speed (4.5 to $14.0 \mathrm{~km} \cdot \mathrm{h}^{-1}$ ), with the initial 142 gradient of the treadmill set to $0 \%$. The treadmill gradient was increased by $1 \%$ every minute 143 until volitional exhaustion. Heart rate was monitored continuously using short-range telemetry 144 (Polar A3, Kempele, Finland), and ratings of perceived exertion (Borg, 1973) were recorded at 145 the end of each minute. Expired air samples were monitored continuously using a breath-by146 breath gas analysis system (Cortex Metalyser 3B, Leipzig, Germany). An average of the breath- 
by-breath oxygen uptake data was taken every $10 \mathrm{~s}$, and $\dot{\mathrm{VO}}_{2}$ peak was defined as the highest 30

148 s rolling average.

149 Visit 2: Magnetic resonance imaging (MRI) scan

150 Each participant underwent an MRI scan in the supine position using a dual-echo Dixon fat and 151 water sequence on a 3-T MRI scanner (MR750w, GE Healthcare, Chicago, USA). A detailed 152 description of the protocol has been reported previously (Borga et al. 2015; West et al. 2016).

153 Briefly seven overlapping image stacks were acquired from the neck to knee with stacks covering 154 the abdomen (stacks 2 to 5) acquired during breath-hold. Additional abdominal slices were 155 acquired with the IDEAL-IQ sequence to assess proton density fat fraction in the liver. Scans 156 were analysed to quantify visceral adipose tissue, abdominal subcutaneous adipose tissue and 157 liver fat fraction using the AMRA Profiler (AMRA Medical AB, Linköping, Sweden) (Borga et 158 al. 2015; West et al. 2016).

\section{Visit 3: Resting metabolic rate and test meal}

160 All premenopausal female participants completed the main trial during the follicular phase of 161 the menstrual cycle (days 6-12) to avoid potential hormonal influences on appetite parameters. 162 Participants were asked to refrain from caffeine, alcohol, and strenuous exercise during the $24 \mathrm{~h}$ 163 before the main trial. A standardised evening meal (3297 kJ, 40\% fat, 39\% carbohydrate, 21\% 164 protein) was consumed the evening before the main trial and only plain water was permitted after 165 the meal until participants arrived at the laboratory the next day.

166 Participants reported to the laboratory at 08:00 after fasting overnight for $12 \mathrm{~h}$. A cannula 167 (Venflon; Becton Dickinson, Helsingborg, Sweden) was inserted into an antecubital vein for 168 venous blood sampling, and participants rested for $60 \mathrm{~min}$ to eliminate any stress effects in 169 response to the cannula (Chandarana et al. 2009). During this time, resting metabolic rate was 170 measured using an open circuit indirect calorimetry system (GEM Nutrition Ltd., Cheshire, 171 England). Participants were asked to lie in a comfortable supine position and were instructed not 172 to talk or sleep, and to move as little as possible during the measurement. The clear hood canopy 173 was placed over the head area, and plastic sheeting attached to the hood was placed around the 174 body to form a seal between the air inside and outside the hood. Oxygen uptake, carbon dioxide 175 production, respiratory exchange ratio and energy expenditure were determined at $30 \mathrm{~s}$ intervals 176 over a $30 \mathrm{~min}$ period. The first $10 \mathrm{~min}$ of data was discarded to account for any initial short-term 177 respiratory artefact. 
178 A fasting venous blood sample and rating of perceived appetite were taken 60 min after the

179 insertion of the cannula. Participants then consumed a standardised breakfast within 15 min 180 marking the start of the postprandial assessment period (09:00; $0 \mathrm{~h})$. Breakfast consisted of a 181 ham and cheese sandwich, milkshake and chocolate biscuit which provided $4435 \mathrm{~kJ}$ of energy 182 (41\% carbohydrate, $18 \%$ protein, $41 \%$ fat). Subsequent venous blood samples and ratings of 183 perceived appetite were taken at $0.5,1$ and $2 \mathrm{~h}$ after the start of the breakfast whilst the 184 participants rested in a semi-supine position.

Appetite perceptions

186 Appetite perceptions (hunger, satisfaction, fullness, prospective food consumption) were 187 assessed using $100 \mathrm{~mm}$ visual analogue scales (Flint et al. 2000). An overall appetite rating was 188 calculated as the mean value of the four appetite ratings once satisfaction and fullness were 189 reverse-scored (Stubbs et al. 2000).

\section{Blood sampling and biochemical analysis}

191 Venous blood samples were collected into pre-chilled EDTA monovettes (Sarstedt, Leicester, 192 UK) for the determination of plasma acylated ghrelin, total PYY, leptin, insulin and glucose 193 concentrations. Monovettes for acylated ghrelin also contained $p$-hydroxymercuribenzoic acid 194 to prevent the degradation of acylated ghrelin by protease and were centrifuged at 2,383 $\mathrm{g}$ for 10 $195 \mathrm{~min}$ at $4^{\circ} \mathrm{C}$ (Burkard, Hertfordhire, UK). The plasma supernatant was aliquoted into a storage 196 tube and $100 \mu \mathrm{L}$ of $1 \mathrm{M}$ hydrochloric acid was added per millilitre of plasma. Samples were re197 centrifuged at 2,383 $\mathrm{g}$ for $5 \mathrm{~min}$ at $4^{\circ} \mathrm{C}$ before being transferred into Eppendorf tubes and stored 198 at $-80^{\circ} \mathrm{C}$ for later analysis. Monovettes for total PYY, leptin, insulin and glucose were 199 centrifuged immediately at $2,383 \mathrm{~g}$ for $10 \mathrm{~min}$ at $4^{\circ} \mathrm{C}$ prior to storage at $-80^{\circ} \mathrm{C}$. Haemoglobin 200 concentration and haematocrit were quantified in duplicate at 0 and $2 \mathrm{~h}$ to estimate the acute 201 change in plasma volume (Dill and Costill, 1974).

202 Commercially available enzyme-linked immunosorbent assays were used to determine the 203 concentrations of plasma acylated ghrelin (Bertin Bioreagent, Montigney le Bretonneux, France), 204 total PYY (Millipore, Billerica, MA, USA), leptin (R\&D Systems, Minneapolis, MN, USA) and 205 insulin (Mercodia, Uppsala, Sweden). Plasma glucose concentrations were determined by 206 enzymatic, colorimetric methods using a benchtop analyser (Pentra 400, HORIBA Medical, 207 Montpellier, France). The within-batch coefficient of variation for acylated ghrelin, total PYY, 208 leptin, insulin and glucose concentrations were 4.3\%, 5.1\%, 8.3\%, 4.7\%, 0.4\%, respectively. 
209 An additional fasting venous blood sample was collected into a 2.7-mL EDTA monovette

210 (Sarstedt, Leicester, UK) and the whole blood sample was stored at $4{ }^{\circ} \mathrm{C}$ to undergo DNA 211 extraction and genotyping. Genomic DNA was extracted from the whole blood samples using 212 the QIAamp DNA Mini kit (QIAGEN, Hilden, Germany). The samples were genotyped for the 213 rs9939609 allele within the FTO gene using the Applied Biosystems TaqMan ${ }^{\circledR}$ (Roche 214 Molecular Systems, Pleasanton, California, USA) genotyping assay and real-time polymerase 215 chain reaction system. Participants were assigned to one of three groups according to their 216 genotype: homozygous major allele, TT (36\%; males $n=23$, females $n=17)$; heterozygous 217 allele, AT (45\%; males $n=22$, females $n=29)$; or homozygous minor allele, AA (19\%; males $218 n=11$, females $n=10$ ). Genotype frequency of FTO rs9939609 was assessed using a goodness219 of-fit chi-square test and did not deviate from Hardy-Weinberg equilibrium $\left(\chi^{2}=0.435, P=\right.$ $2200.509)$.

223 Participants wore an ActiGraph GT3X+ accelerometer (ActiGraph, Pensacola, USA) on an 224 elasticated belt on the waist above the mid-line of the thigh on their non-dominant side of the 225 body. The device was initialised at a frequency of $100 \mathrm{HZ}$ and downloaded using ActiLife 226 software v6.11.8 and firmware version 2.0.0. ActiGraph data were downloaded in 60-seconds 227 epochs and physical activity was classified as low, light and moderate-to-vigorous. Participants 228 also wore an activPAL3 accelerometer (PAL Technologies Ltd., Glasgow, UK), attached 229 directly to the skin on the midline of the anterior aspect of the thigh in line with the ActiGraph $230 \mathrm{GT} 3 \mathrm{X}+$ accelerometer. The activPAL3 determines posture using information derived from 231 accelerations of the thigh, including the gravitational component, using a triaxial accelerometer 232 (Atkin et al. 2012). The activPAL3 is a valid measure of time spent sitting/lying, standing, and 233 walking in adults (Kozey-Keadle et al. 2011). ActivPAL3 sitting time data were retrieved and 234 clustered into 60-seconds epochs using a customized spreadsheet. Participants were advised to 235 wear both devices concurrently and continuously over a 7-day period. Non-wear time and sleep 236 time were removed from the analysis and moderate-to-vigorous physical activity (MVPA) and 237 sitting time data were averaged over the seven-day period.

\section{Statistical analyses}

239 We estimated the effect size detection sensitivity given our sample size using NQuery (version 2403 , Statistical Solutions, Cork, Ireland). For a total sample size of 110 and three study groups, we 
241 estimated that a "medium" (Cohen, 1998) Eta $^{2}$ value of 0.18 would be detected in a univariable 242 model as statistically significant $(P<0.050)$ with power of $90 \%$.

243 Postprandial overall appetite and plasma concentrations of acylated ghrelin, total PYY, insulin 244 and glucose are presented relative to baseline values (delta) to minimise the potential influence 245 of day-to-day biological variability (Deighton et al. 2013, 2014). Total area under the curve 246 (AUC) values were calculated using the trapezoidal method. Correction of blood parameter concentrations for acute changes in plasma volume had a negligible influence on our findings and, therefore, the unadjusted plasma concentrations are displayed for simplicity.

Multivariable general linear models were used to quantify the mean differences (and 95\% confidence intervals) between FTO rs9939609 genotype groups for each fasting and postprandial appetite outcome. The eta-squared statistic (with associated $90 \%$ confidence interval) was also estimated for each model and each outcome (Kline, 2004; Steiger, 2004). This statistic is interpreted in a similar way as the coefficient of determination, where $100 \mathrm{x}$ eta-squared gives the explained variance attributable to the FTO groups. A 90\% rather than a $95 \%$ confidence interval is reported because the eta-squared statistic can only be positive in sign. The model residuals of the appetite outcome variables were explored for parity to a Gaussian distribution using histograms. The model residuals for fasting acylated ghrelin and insulin concentrations were observed to show a positively skewed distribution so these data were logarithmicallytransformed prior to analysis (Bland and Altman, 1996). Three models were used for each of the fasting and postprandial appetite outcomes, as follows:

1. Model I: Univariable models with FTO rs9939609 genotype as single fixed effect;

2. Model II: A multivariable model based on the selection of matched covariates studied by Karra et al. (2013), i.e., age, fat mass and visceral adipose tissue. FTO rs9939609 genotype was entered as a fixed effect and sex, age, fat mass and visceral adipose tissue were entered as covariates;

3. Model III: A multivariable model, where FTO rs9939609 genotype was entered as a fixed effect and sex, age, BMI, $\mathrm{V}_{2}$ peak, resting metabolic rate, visceral adipose tissue, abdominal subcutaneous adipose tissue, liver fat, sitting time and MVPA were entered as covariates. Rather than the now discouraged use of stepwise selection procedures, these covariates were included based on their hypothesised influence on the outcome variables, while considering the potential that some predictors were mathematically coupled (Flom and Cassell, 2007; Whittingham et al. 2006). For 
example, total fat mass was excluded from this model because multiple specific adiposity parameters were considered.

275 The covariates in models II and III were each standardised prior to analysis by dividing each 276 datum by twice the respective SD (Gelman and Pardoe, 2007). In sensitivity analyses, model III 277 was also run with (i) waist circumference replacing BMI; (ii) percentage body fat replacing BMI; 278 and (iii) with a sex-by-genotype interaction term.

279 Univariable general linear models with FTO rs9939609 genotype as a single fixed effect were 280 used to quantify differences between genotype groups for body mass, BMI and fat mass. 281 Between-sex differences in participant characteristics and appetite-related outcomes in the 282 fasting and postprandial states were assessed using univariable general linear models with sex 283 as a single fixed effect. Sex-specific univariable Pearson's correlation coefficients were 284 quantified between appetite-related outcomes and individual characteristics, and between 285 appetite-related blood parameters and perceived appetite.

$28695 \%$ confidence intervals $(95 \% \mathrm{CI})$ were quantified for correlation coefficients. P-values are 287 expressed in exact terms apart from very low values, which are expressed as $P<0.001$. A 288 threshold of statistical significance was accepted as $P<0.050$, although we deemed a $P$ value of $289<0.005$ as a stronger indication of potentially more reproducible results in line with recent advice 290 (Benjamin et al. 2017). All statistical analyses were performed in SPSS (v.23, IBM Corporation, 291 New York, USA).

\section{RESULTS}

\section{Missing data}

295 Due to technical issues with the equipment, resting metabolic rate is presented for 107 296 participants (53 males), sitting time for 96 participants (47 males) and MVPA for 100 297 participants (49 males). Eleven participants were unable to undertake the MRI scan for safety 298 reasons and, therefore, visceral adipose tissue and abdominal subcutaneous adipose tissue are 299 presented for 101 participants (50 males). Liver fat could not be quantified from some images 300 due to motion artefacts and, therefore, data is presented for 97 participants (48 males).

\section{$301 \quad$ Participant characteristics and appetite-related outcomes}

302 Participant characteristics, perceived appetite and appetite-related blood parameters in the 303 fasting and postprandial states are presented in Table 1. Postprandial delta values for acylated 
304 ghrelin, total PYY, insulin and glucose concentrations and perceived overall appetite are 305 presented in Figure 1. 
Table 1. Participant characteristics and appetite outcomes in the fasting and postprandial states.

\begin{tabular}{|c|c|c|c|c|c|c|}
\hline & $\begin{array}{c}\text { All } \\
(n=112)\end{array}$ & $\begin{array}{c}\text { Range } \\
(\min \text { to } \max )\end{array}$ & $\begin{array}{c}\text { Men } \\
(n=56)\end{array}$ & $\begin{array}{l}\text { Women } \\
(\mathrm{n}=\mathbf{5 6})\end{array}$ & $\boldsymbol{P}$ & $\begin{array}{c}\text { Mean difference } \\
95 \% \mathrm{CI}\end{array}$ \\
\hline Age (years) & $34(9)$ & 18 to 50 & $35.3(9.7)$ & $33.5(9.1)$ & 0.303 & -5.4 to 1.7 \\
\hline Stature $(\mathrm{cm})$ & $171.0(9.2)$ & 149.1 to 200.4 & $178.5(6.6)$ & $165.3(6.2)$ & $<0.001$ & -15.6 to -10.8 \\
\hline Body mass (kg) & $74.9(14.7)$ & 48.5 to 140.4 & $83.3(12.9)$ & $66.5(11.1)$ & $<0.001$ & -21.2 to -12.2 \\
\hline Body mass index $\left(\mathrm{kg} \cdot \mathrm{m}^{-2}\right)$ & $25.2(3.9)$ & 18.4 to 40.3 & $26.1(3.7)$ & $24.4(4.0)$ & 0.016 & -3.2 to -0.3 \\
\hline Waist circumference $(\mathrm{cm})$ & $82.7(10.8)$ & 62.4 to 125.0 & $88.4(9.8)$ & $77.0(8.7)$ & $<0.001$ & -14.9 to -8.0 \\
\hline Fat mass $(\mathrm{kg})$ & $16.9(8.4)$ & 3.5 to 47.8 & $15.5(9.1)$ & $18.2(7.4)$ & 0.078 & -0.3 to 5.9 \\
\hline Fat free mass $(\mathrm{kg})$ & $58.1(12.2)$ & 36.8 to 92.6 & $67.8(8.8)$ & $48.3(5.5)$ & $<0.001$ & -22.2 to -16.8 \\
\hline$\dot{\mathrm{V}} \mathrm{O}_{2}$ peak $\left(\mathrm{mL} \cdot \mathrm{kg} \cdot \mathrm{min}^{-1}\right)$ & $44.0(9.3)$ & 21.0 to 81.0 & $49.0(9.3)$ & $39.0(6.1)$ & $<0.001$ & -13.0 to -7.1 \\
\hline Resting metabolic rate (kcal)* & $1617(322)$ & 889 to 2567 & $1808(290)$ & $1430(232)$ & $<0.001$ & -478 to -277 \\
\hline Visceral adipose tissue $(\mathrm{L})^{*}$ & $1.70(1.26)$ & 0.11 to 6.22 & $2.27(1.41)$ & $1.14(0.75)$ & $<0.001$ & -1.58 to -0.69 \\
\hline $\begin{array}{l}\text { Abdominal subcutaneous } \\
\text { adipose tissue (L)* }\end{array}$ & $5.39(3.02)$ & 1.45 to 16.86 & $4.49(2.39)$ & $6.27(3.33)$ & 0.003 & 0.64 to 2.93 \\
\hline Liver fat $(\%)^{*}$ & $2.12(1.81)$ & 0.46 to 10.45 & $2.62(2.19)$ & $1.63(1.16)$ & 0.006 & -1.69 to -0.28 \\
\hline Sitting time $\left(\min \cdot \text { day }^{-1}\right)^{*}$ & $509(85)$ & 256 to 737 & $513(73)$ & $504(95)$ & 0.630 & -43 to 26 \\
\hline MVPA $\left(\min \cdot \text { day }^{-1}\right)^{*}$ & $55(31)$ & 11 to 163 & $57(30)$ & $54(33)$ & 0.706 & -15 to 10 \\
\hline Fasting leptin $\left(\mathrm{ng} \cdot \mathrm{mL}^{-1}\right)$ & $8.62(8.63)$ & 1.34 to 43.85 & $4.07(3.08)$ & $13.16(9.95)$ & $<0.001$ & 6.33 to 11.84 \\
\hline $\begin{array}{l}\text { Fasting acylated ghrelin } \\
\left(\mathrm{pg} \cdot \mathrm{mL}^{-1}\right)\end{array}$ & $173.6(491.8)$ & 12.0 to 4410.6 & $103.3(108.8)$ & $243.8(682.9)$ & 0.131 & -42.6 to 323.6 \\
\hline Fasting total PYY $\left(\mathrm{pg} \cdot \mathrm{mL}^{-1}\right)$ & $117.5(50.5)$ & 13.6 to 270.0 & $121.9(47.9)$ & $113.0(53.1)$ & 0.353 & -27.8 to 10.0 \\
\hline Fasting insulin $\left(\mathrm{pmol} \cdot \mathrm{L}^{-1}\right)$ & $23.3(15.0)$ & 2.9 to 97.1 & $22.9(14.3)$ & $23.6(15.8)$ & 0.825 & -5.0 to 6.3 \\
\hline Fasting glucose $\left(\mathrm{mmol} \cdot \mathrm{L}^{-1}\right)$ & $5.24(0.43)$ & 4.29 to 6.56 & $5.37(0.43)$ & $5.12(0.39)$ & 0.001 & -0.41 to -0.10 \\
\hline Fasting overall appetite (mm) & $70.8(15.3)$ & 19 to 95 & $71.2(13.4)$ & $70.4(17.1)$ & 0.787 & -6.5 to 5.0 \\
\hline $\begin{array}{l}\text { Acylated ghrelin delta AUC (2 } \\
\left.\mathrm{h}, \mathrm{pg} \cdot \mathrm{mL}^{-1}\right)\end{array}$ & $-87.9(126.6)$ & -1183.5 to 165.8 & $-51.3(56.3)$ & $-124.6(162.6)$ & 0.002 & -118.9 to -27.8 \\
\hline $\begin{array}{l}\text { Total PYY delta AUC } \\
\left(2 \mathrm{~h}, \mathrm{pg} \cdot \mathrm{mL}^{-1}\right)\end{array}$ & $101.6(61.0)$ & -26.4 to 340.7 & $99.0(62.4)$ & $104.2(59.9)$ & 0.653 & -17.7 to 28.1 \\
\hline $\begin{array}{l}\text { Insulin delta AUC } \\
\left(2 \mathrm{~h}, \mathrm{pg} \cdot \mathrm{mL}^{-1}\right)\end{array}$ & $420.6(236.8)$ & 121.3 to 1485.8 & $403.9(256.6)$ & $437.3(216.3)$ & 0.458 & -55.5 to 122.2 \\
\hline $\begin{array}{l}\text { Glucose delta AUC } \\
\left(2 \mathrm{~h}, \mathrm{pg} \cdot \mathrm{mL}^{-1}\right)\end{array}$ & $0.77(1.59)$ & -2.20 to 5.79 & $0.54(1.37)$ & $1.00(1.77)$ & 0.125 & -0.13 to 1.05 \\
\hline $\begin{array}{l}\text { Overall appetite delta AUC ( } 2 \\
\left.\mathrm{~h}, \mathrm{pg} \cdot \mathrm{mL}^{-1}\right)\end{array}$ & $-77.4(34.4)$ & -150.0 to -14.0 & $-65.7(30.9)$ & $-89.1(34.0)$ & $<0.001$ & -35.5 to -11.1 \\
\hline
\end{tabular}

Values are mean (SD). $P$ values and $95 \% \mathrm{CI}$ are from univariable general linear models with sex as a single fixed effect. $* \mathrm{n}=107$ (53 males) for resting metabolic rate, 96 (47 males) for sitting time, 100 (49 males) for MVPA, 101 (50 males) for visceral adipose tissue and abdominal subcutaneous adipose tissue, and 97 (48 males) for liver fat.

AUC, area under the curve; CI, confidence interval; MVPA, moderate-to-vigorous physical activity, PYY, peptide YY; $\dot{\mathrm{V}} \mathrm{O}_{2}$ peak, peak oxygen uptake. 
A

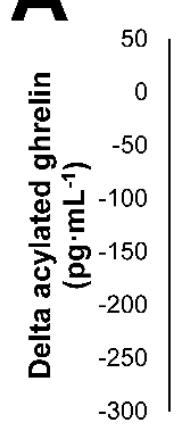

C

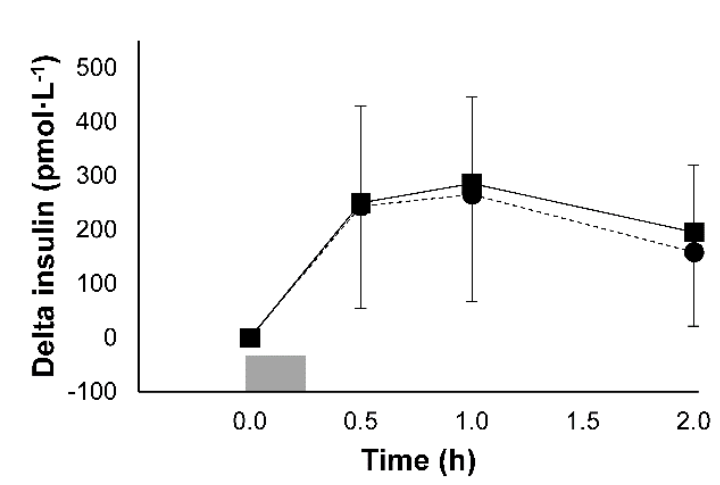

B

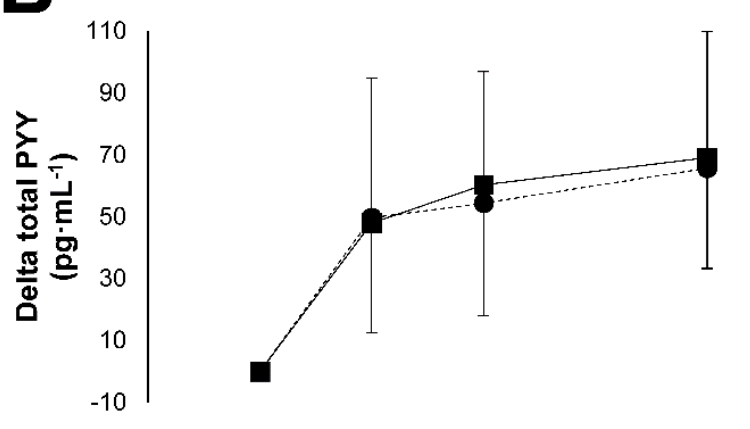

D

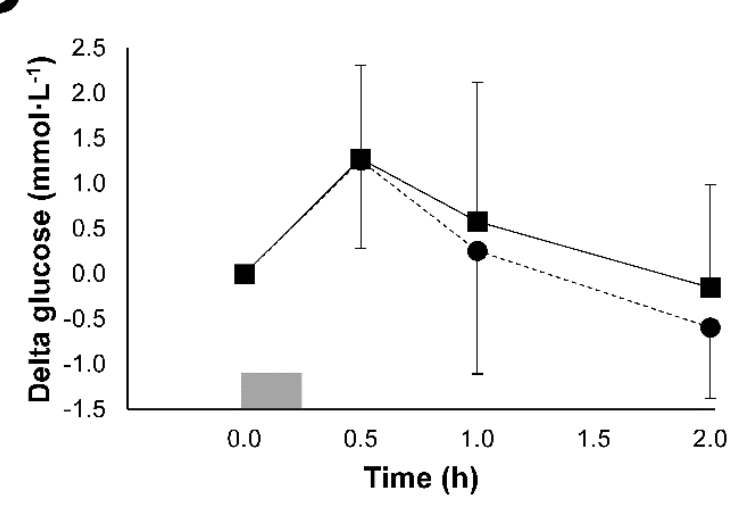

Males

- Females

E

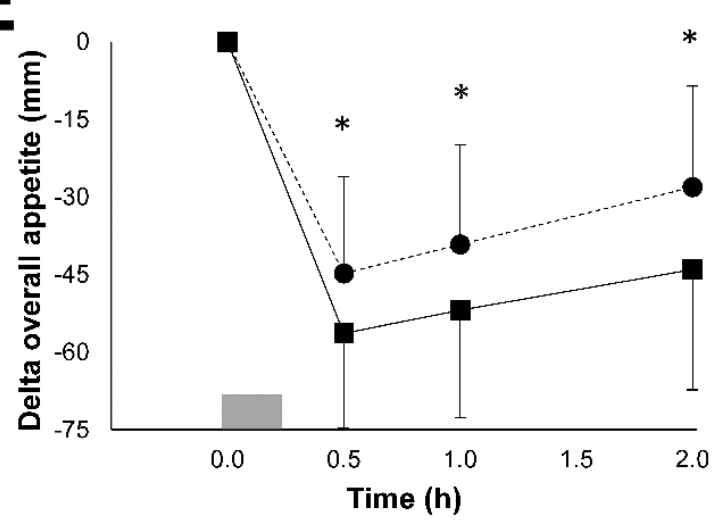

Figure 1. Delta postprandial values for acylated ghrelin (A), total peptide YY (PYY) (B), insulin (C), glucose (D) and overall perceived appetite (E) in 56 males and 56 females. Grey rectangles indicate meal consumed within 15 min. Values are presented as mean (SD). Linear mixed models identified main effects of sex for delta acylated ghrelin, delta glucose and delta overall appetite $(\mathrm{P} \leq 0.045)$, main effects of time for all outcomes $(\mathrm{P}<0.001)$ and a sex-by-time interaction for delta appetite $(\mathrm{P}=0.004)$. $\mathrm{P}<0.001$ for post-hoc analysis of sex-by-time interaction between males and females. 


\section{Univariable and multivariable general linear models}

302 No statistically significant influence of the FTO rs9939609 genotype was identified for body 303 mass $\left(\mathrm{Eta}^{2}=0.027, P=0.234\right)$, BMI $\left(\mathrm{Eta}^{2}=0.003, P=0.688\right)$ or fat mass $\left(\mathrm{Eta}^{2}=0.025, P=\right.$ $3040.259)$.

\section{$305 \quad$ Fasting appetite-related outcomes}

306 Separate univariate modelling (model I) did not reveal any statistically significant influence of 307 the FTO rs9939609 genotype on fasting acylated ghrelin, total PYY, insulin, glucose, leptin or 308 overall appetite $(P \geq 0.501)$ (Table 2). Similarly, no significant effect of the FTO rs9939609 309 genotype was detected on fasting appetite-related outcomes in model II $(P \geq 0.098)$ or model III $310(P \geq 0.453)$ (Table 2$)$. All eta-squared values were very low $(<0.05)$. Replacing BMI with waist 311 circumference, replacing BMI with body fat percentage, and including a sex-by-genotype 312 interaction term in the sensitivity analyses did not result in a significant effect of the FTO 313 rs9939609 genotype on any of the fasting appetite-related outcomes $(P \geq 0.470, P \geq 0.437, P \geq$ 3140.455 , respectively).

Postprandial appetite-related outcomes

316 Separate univariate modelling (model I) did not reveal any statistically significant influence of 317 the FTO rs9939609 genotype on delta AUC for acylated ghrelin, total PYY, insulin, glucose, 318 leptin or overall appetite $(P \geq 0.322)$ (Table 3$)$. Similarly, no significant effect of the FTO 319 rs9939609 genotype was detected on delta AUC for any of the appetite-related outcomes in 320 model II $(P \geq 0.271)$ or model III $(P \geq 0.186)$ (Table 3$)$. Again, all eta-squared values were very 321 low $(<0.05)$. Replacing BMI with waist circumference, replacing BMI with body fat percentage, 322 and including a sex-by-genotype interaction term in the sensitivity analyses did not result in a 323 significant effect of the FTO rs9939609 genotype on any of the postprandial appetite-related 324 outcomes $(P \geq 0.133, P \geq 0.102, P \geq 0.206$, respectively). A sensitivity analysis was undertaken 325 on all the postprandial outcomes AUC by adding the respective fasting measurement as a 326 covariate to the model. Again, no statistically significant differences between FTO groups could 327 be detected $(P>0.200)$ and mean differences were small. 
Table 2. Estimated marginal means from the multivariable general linear models used to quantify the differences between FTO rs9939609 genotype groups in each fasting appetite outcome.

\begin{tabular}{|c|c|c|c|c|c|c|c|c|c|}
\hline & \multicolumn{3}{|c|}{ Model I } & \multicolumn{3}{|c|}{ Model II } & \multicolumn{3}{|c|}{ Model III } \\
\hline & $\underset{(n=49)}{\mathbf{A T}}$ & $\begin{array}{c}\mathbf{A A} \\
(\mathrm{n}=21)\end{array}$ & $\begin{array}{c}\text { TT } \\
(n=40)\end{array}$ & $\begin{array}{c}\mathbf{A T} \\
(\mathrm{n}=45)\end{array}$ & $\begin{array}{c}\mathbf{A A} \\
(\mathrm{n}=18)\end{array}$ & $\begin{array}{c}\text { TT } \\
(\mathbf{n}=37)\end{array}$ & $\begin{array}{c}\mathbf{A T} \\
(\mathrm{n}=34)\end{array}$ & $\begin{array}{c}\text { AA } \\
(\mathbf{n}=17)\end{array}$ & $\begin{array}{c}\text { TT } \\
(n=28)\end{array}$ \\
\hline \multirow{2}{*}{$\begin{array}{l}\text { Fasting acylated } \\
\text { ghrelin } \\
\left(\log \mathrm{pg} \cdot \mathrm{mL}^{-1}\right)\end{array}$} & $\begin{array}{c}4.47 \\
(4.25 \text { to } 4.69)\end{array}$ & $\begin{array}{c}4.59 \\
(4.26 \text { to } 4.92)\end{array}$ & $\begin{array}{c}4.51 \\
(4.27 \text { to } 4.75)\end{array}$ & $\begin{array}{c}4.42 \\
(4.18 \text { to } 4.65)\end{array}$ & $\begin{array}{c}4.57 \\
\text { (4.20 to } 4.94)\end{array}$ & $\begin{array}{c}4.57 \\
(4.30 \text { to } 4.83)\end{array}$ & $\begin{array}{c}4.42 \\
\text { (4.20 to } 4.64)\end{array}$ & $\begin{array}{c}4.56 \\
(4.23 \text { to } 4.88)\end{array}$ & $\begin{array}{c}4.29 \\
(4.03 \text { to } 4.54)\end{array}$ \\
\hline & \multicolumn{3}{|c|}{$\mathrm{Eta}^{2}=0.003$ (90\% CI: $\left.0.000-0.023\right), P=0.835$} & \multicolumn{3}{|c|}{$\mathrm{Eta}^{2}=0.009$ (90\% CI: $\left.0.000-0.047\right), P=0.660$} & \multicolumn{3}{|c|}{$\mathrm{Eta}^{2}=0.024(90 \%$ CI: $0.000-0.091), P=0.453$} \\
\hline \multirow[t]{2}{*}{$\begin{array}{l}\text { Fasting total PYY } \\
\left(\mathrm{pg} \cdot \mathrm{mL}^{-1}\right)\end{array}$} & $\begin{array}{c}110.3 \\
\text { (96.1 to } 124.5)\end{array}$ & $\begin{array}{c}123.5 \\
(101.8 \text { to } 145.2)\end{array}$ & $\begin{array}{c}120.4 \\
(104.7 \text { to } 136.2)\end{array}$ & $\begin{array}{c}109.2 \\
(94.0 \text { to } 124.4)\end{array}$ & $\begin{array}{c}123.6 \\
(100.2 \text { to } 147.0)\end{array}$ & $\begin{array}{c}122.4 \\
(105.7 \text { to } 139.1)\end{array}$ & $\begin{array}{c}114.3 \\
\text { (97.6 to } 130.9)\end{array}$ & $\begin{array}{c}117.2 \\
\text { (93.3 to } 141.0)\end{array}$ & $\begin{array}{c}114.1 \\
\text { (95.0 to } 133.2)\end{array}$ \\
\hline & \multicolumn{3}{|c|}{$\mathrm{Eta}^{2}=0.013(90 \%$ CI: $0.000-0.055), P=0.501$} & \multicolumn{3}{|c|}{$\mathrm{Eta}^{2}=0.018$ (90\% CI: $\left.0.000-0.069\right), P=0.434$} & \multicolumn{3}{|c|}{$\mathrm{Eta}^{2}=0.001$ (90\% CI: $\left.0.000-0.014\right), P=0.977$} \\
\hline \multirow[t]{2}{*}{$\begin{array}{l}\text { Fasting insulin } \\
\left(\log \mathrm{pmol} \cdot \mathrm{L}^{-1}\right)\end{array}$} & $\begin{array}{c}3.00 \\
(2.83 \text { to } 3.16)\end{array}$ & $\begin{array}{c}2.87 \\
\text { (2.61 to } 3.12)\end{array}$ & $\begin{array}{c}2.97 \\
\text { (2.79 to } 3.16)\end{array}$ & $\begin{array}{c}3.03 \\
(2.88 \text { to } 3.19)\end{array}$ & $\begin{array}{c}2.93 \\
\text { (2.70 to } 3.17)\end{array}$ & $\begin{array}{c}2.96 \\
(2.79 \text { to } 3.13)\end{array}$ & $\begin{array}{c}3.01 \\
\text { (2.81 to } 3.20 \text { ) }\end{array}$ & $\begin{array}{c}2.98 \\
(2.70 \text { to } 3.27)\end{array}$ & $\begin{array}{c}2.95 \\
\text { (2.72 to } 3.18)\end{array}$ \\
\hline & \multicolumn{3}{|c|}{$\mathrm{Eta}^{2}=0.007$ (90\% CI: $\left.0.000-0.038\right), P=0.699$} & \multicolumn{3}{|c|}{$\mathrm{Eta}^{2}=0.007$ (90\% CI: $\left.0.000-0.041\right), P=0.716$} & \multicolumn{3}{|c|}{$\mathrm{Eta}^{2}=0.002$ (90\% CI: $\left.0.000-0.028\right), P=0.935$} \\
\hline \multirow[t]{2}{*}{$\begin{array}{l}\text { Fasting glucose } \\
\left(\mathrm{mmol} \cdot \mathrm{L}^{-1}\right)\end{array}$} & $\begin{array}{c}5.23 \\
\text { (5.11 to } 5.36)\end{array}$ & $\begin{array}{c}5.28 \\
(5.09 \text { to } 5.47)\end{array}$ & $\begin{array}{c}5.22 \\
\text { (5.09 to } 5.36)\end{array}$ & $\begin{array}{c}5.27 \\
\text { (5.15 to } 5.38)\end{array}$ & $\begin{array}{c}5.28 \\
\text { (5.11 to } 5.46)\end{array}$ & $\begin{array}{c}5.14 \\
(5.02 \text { to } 5.27)\end{array}$ & $\begin{array}{c}5.24 \\
\text { (5.10 to } 5.38)\end{array}$ & $\begin{array}{c}5.30 \\
(5.10 \text { to } 5.51)\end{array}$ & $\begin{array}{c}5.16 \\
(5.00 \text { to } 5.32)\end{array}$ \\
\hline & \multicolumn{3}{|c|}{ Eta $^{2}=0.002(90 \%$ CI: $0.000-0.016), P=0.882$} & \multicolumn{3}{|c|}{$\mathrm{Eta}^{2}=0.027(90 \%$ CI: $0.000-0.087), P=0.278$} & \multicolumn{3}{|c|}{$\mathrm{Eta}^{2}=0.018$ (90\% CI: $\left.0.000-0.078\right), P=0.553$} \\
\hline \multirow[t]{2}{*}{$\begin{array}{l}\text { Fasting leptin } \\
\left(\mathrm{ng} \cdot \mathrm{mL}^{-1}\right)\end{array}$} & $\begin{array}{c}9.17 \\
(6.70 \text { to } 11.65)\end{array}$ & $\begin{array}{c}8.06 \\
(4.27 \text { to } 11.84)\end{array}$ & $\begin{array}{c}7.95 \\
(5.21 \text { to } 10.69)\end{array}$ & $\begin{array}{c}9.77 \\
\text { (8.15 to } 11.39)\end{array}$ & $\begin{array}{c}6.67 \\
\text { (4.17 to } 9.17)\end{array}$ & $\begin{array}{c}7.93 \\
\text { (6.15 to } 9.71)\end{array}$ & $\begin{array}{c}9.76 \\
\text { (7.91 to } 11.62)\end{array}$ & $\begin{array}{c}8.71 \\
\text { (6.05 to } 11.37)\end{array}$ & $\begin{array}{c}8.72 \\
\text { (6.59 to } 10.85)\end{array}$ \\
\hline & \multicolumn{3}{|c|}{$\mathrm{Eta}^{2}=0.005$ (90\% CI: $\left.0.000-0.030\right), P=0.779$} & \multicolumn{3}{|c|}{$\mathrm{Eta}^{2}=0.049$ (90\% CI: $\left.0.000-0.122\right), P=0.098$} & \multicolumn{3}{|c|}{$\mathrm{Eta}^{2}=0.010(90 \%$ CI: $0.000-0.057), P=0.713$} \\
\hline \multirow[t]{2}{*}{$\begin{array}{l}\text { Fasting overall } \\
\text { appetite (mm) }\end{array}$} & $\begin{array}{c}70.0 \\
\text { (65.7 to } 74.4)\end{array}$ & $\begin{array}{c}69.6 \\
(63.0 \text { to } 76.2)\end{array}$ & $\begin{array}{c}72.2 \\
(67.4 \text { to } 77.0)\end{array}$ & $\begin{array}{c}67.6 \\
(63.0 \text { to } 72.3)\end{array}$ & $\begin{array}{c}70.2 \\
(63.0 \text { to } 77.4)\end{array}$ & $\begin{array}{c}72.4 \\
(67.3 \text { to } 77.6)\end{array}$ & $\begin{array}{c}66.8 \\
\text { (60.9 to } 72.7 \text { ) }\end{array}$ & $\begin{array}{c}68.9 \\
\text { (60.4 to } 77.3)\end{array}$ & $\begin{array}{c}69.3 \\
(62.5 \text { to } 76.0)\end{array}$ \\
\hline & \multicolumn{3}{|c|}{$\mathrm{Eta}^{2}=0.005$ (90\% CI: $\left.0.000-0.033\right), P=0.748$} & \multicolumn{3}{|c|}{$\mathrm{Eta}^{2}=0.019$ (90\% CI: $\left.0.000-0.072\right), P=0.402$} & \multicolumn{3}{|c|}{$\mathrm{Eta}^{2}=0.005$ (90\% CI: $\left.0.000-0.034\right), P=0.850$} \\
\hline
\end{tabular}

Model I: Univariable model with FTO rs9939609 genotype as single fixed effect. Model II: Multivariable model with FTO rs9939609 genotype as a fixed effect and sex, age, fat mass and visceral adipose tissue as covariates. Model III: Multivariable model with FTO rs9939609 genotype as a fixed effect and sex, age, body mass index, peak oxygen uptake, resting metabolic rate, visceral adipose tissue, abdominal subcutaneous adipose tissue, liver fat, sitting time and moderate-to-vigorous physical activity as covariates.

Values are mean (95\% confidence interval (CI)). Eta ${ }^{2}, 90 \%$ CI and $P$-values are from the fixed effect of the FTO rs9939609 genotype group. 
Table 3. Estimated marginal means from the multivariable general linear models used to quantify the differences between FTO rs9939609 genotype groups in each postprandial appetite outcome.

\begin{tabular}{|c|c|c|c|c|c|c|c|c|c|}
\hline & \multicolumn{3}{|c|}{ Model I } & \multicolumn{3}{|c|}{ Model II } & \multicolumn{3}{|c|}{ Model III } \\
\hline & $\begin{array}{c}\mathrm{AT} \\
(\mathrm{n}=49)\end{array}$ & $\begin{array}{c}\mathbf{A A} \\
(\mathbf{n}=\mathbf{2 1})\end{array}$ & $\begin{array}{c}\text { TT } \\
(n=40)\end{array}$ & $\begin{array}{c}\mathrm{AT} \\
(\mathrm{n}=\mathbf{4 5})\end{array}$ & $\begin{array}{c}\text { AA } \\
(n=18)\end{array}$ & $\begin{array}{c}\text { TT } \\
(\mathbf{n}=37)\end{array}$ & $\begin{array}{c}\mathbf{A T} \\
(\mathbf{n}=34)\end{array}$ & $\begin{array}{c}\mathbf{A A} \\
(\mathbf{n}=\mathbf{1 7})\end{array}$ & $\begin{array}{c}\text { TT } \\
(\mathbf{n}=\mathbf{2 8})\end{array}$ \\
\hline \multirow{2}{*}{$\begin{array}{l}\text { Acylated ghrelin } \\
\text { delta AUC } \\
\left(2 \mathrm{~h} \mathrm{pg} \cdot \mathrm{mL}^{-1}\right)\end{array}$} & $\begin{array}{c}-76.0 \\
110.8 \text { to }-41.2)\end{array}$ & $\begin{array}{c}-86.3 \\
(-139.5 \text { to }-33.1)\end{array}$ & $\begin{array}{c}-96.3 \\
(-134.9 \text { to }-57.8)\end{array}$ & $\begin{array}{c}-69.5 \\
107.1 \text { to }-32.0)\end{array}$ & $\begin{array}{c}-93.1 \\
(-151.1 \text { to }-35.0)\end{array}$ & $\begin{array}{c}-103.2 \\
(-144.5 \text { to }-61.8)\end{array}$ & $\begin{array}{c}-87.4 \\
(-106.9 \text { to }-67.9)\end{array}$ & $\begin{array}{c}-87.0 \\
(-114.9 \text { to }-59.0)\end{array}$ & $\begin{array}{c}-67.8 \\
(-90.2 \text { to }-45.4)\end{array}$ \\
\hline & \multicolumn{3}{|c|}{$\mathrm{Eta}^{2}=0.006$ (90\% CI: $\left.0.000-0.034\right), P=0.740$} & \multicolumn{3}{|c|}{$\mathrm{Eta}^{2}=0.015$ (90\% CI: $\left.0.000-0.063\right), P=0.494$} & \multicolumn{3}{|c|}{$\mathrm{Eta}^{2}=0.026(90 \%$ CI: $0.000-0.097), P=0.414$} \\
\hline \multirow{2}{*}{$\begin{array}{l}\text { Total PYY delta } \\
\text { AUC } \\
\left(2 \mathrm{~h} \mathrm{pg} \cdot \mathrm{mL}^{-1}\right)\end{array}$} & $\begin{array}{c}101.1 \\
4.2 \text { to } 118.1)\end{array}$ & $\begin{array}{c}89.7 \\
\text { (63.8 to 115.6) }\end{array}$ & $\begin{array}{c}113.4 \\
\text { (94.7 to } 132.2 \text { ) }\end{array}$ & $\begin{array}{c}98.5 \\
80.2 \text { to } 116.8)\end{array}$ & $\begin{array}{c}86.5 \\
\text { (58.2 to } 114.8)\end{array}$ & $\begin{array}{c}113.7 \\
(93.5 \text { to } 133.8)\end{array}$ & $\begin{array}{c}103.5 \\
\text { (81.2 to } 125.8)\end{array}$ & $\begin{array}{c}80.4 \\
\text { (48.4 to } 112.4 \text { ) }\end{array}$ & $\begin{array}{c}120.1 \\
\text { (94.4 to } 145.7 \text { ) }\end{array}$ \\
\hline & \multicolumn{3}{|c|}{$\mathrm{Eta}^{2}=0.021(90 \%$ CI: $0.000-0.072), P=0.322$} & \multicolumn{3}{|c|}{$\mathrm{Eta}^{2}=0.028(90 \%$ CI: $0.000-0.088), P=0.271$} & \multicolumn{3}{|c|}{$\mathrm{Eta}^{2}=0.050(90 \%$ CI: $0.000-0.137), P=0.186$} \\
\hline \multirow[t]{2}{*}{$\begin{array}{l}\text { Insulin delta AUC } \\
\left(2 \mathrm{~h} \mathrm{pmol} \cdot \mathrm{L}^{-1}\right)\end{array}$} & $\begin{array}{c}411 \\
345 \text { to } 476)\end{array}$ & $\begin{array}{c}404 \\
\text { (303 to } 503 \text { ) }\end{array}$ & $\begin{array}{c}432 \\
(359 \text { to } 504)\end{array}$ & $\begin{array}{c}409 \\
\text { (342 to } 477 \text { ) }\end{array}$ & $\begin{array}{c}415 \\
\text { (311 to } 519)\end{array}$ & $\begin{array}{c}430 \\
\text { (356 to } 504 \text { ) }\end{array}$ & $\begin{array}{c}411 \\
(330 \text { to } 492)\end{array}$ & $\begin{array}{c}429 \\
\text { (313 to } 545)\end{array}$ & $\begin{array}{c}463 \\
(370 \text { to } 556)\end{array}$ \\
\hline & \multicolumn{3}{|c|}{$\mathrm{Eta}^{2}=0.002(90 \%$ CI: $0.000-0.017), P=0.875$} & \multicolumn{3}{|c|}{$\mathrm{Eta}^{2}=0.002(90 \%$ CI: $0.000-0.022), P=0.921$} & \multicolumn{3}{|c|}{$\mathrm{Eta}^{2}=0.010(90 \%$ CI: $0.000-0.055), P=0.728$} \\
\hline \multirow{2}{*}{$\begin{array}{l}\text { Glucose delta } \\
\text { AUC } \\
\left(2 \mathrm{~h} \mathrm{mmol} \cdot \mathrm{L}^{-1}\right)\end{array}$} & $\begin{array}{c}0.66 \\
\text { (0.21 to } 1.12)\end{array}$ & $\begin{array}{c}0.60 \\
(-0.10 \text { to } 1.30)\end{array}$ & $\begin{array}{c}1.01 \\
(0.51 \text { to } 1.52)\end{array}$ & $\begin{array}{c}0.60 \\
\text { (0.19 to } 1.02)\end{array}$ & $\begin{array}{c}0.54 \\
(-0.09 \text { to } 1.18)\end{array}$ & $\begin{array}{c}0.79 \\
\text { (0.34 to } 1.25)\end{array}$ & $\begin{array}{c}0.68 \\
\text { (0.19 to } 1.17)\end{array}$ & $\begin{array}{c}0.44 \\
(-0.26 \text { to } 1.14)\end{array}$ & $\begin{array}{c}0.88 \\
\text { (0.32 to } 1.44)\end{array}$ \\
\hline & \multicolumn{3}{|c|}{$\mathrm{Eta}^{2}=0.012(90 \%$ CI: $0.000-0.054), P=0.511$} & \multicolumn{3}{|c|}{$\mathrm{Eta}^{2}=0.006(90 \%$ CI: $0.000-0.036), P=0.766$} & \multicolumn{3}{|c|}{$\mathrm{Eta}^{2}=0.013(90 \%$ CI: $0.000-0.066), P=0.642$} \\
\hline $\begin{array}{l}\text { Overall appetite } \\
\text { delta AUC } \\
(2 \mathrm{~h} \mathrm{~mm})\end{array}$ & $\begin{array}{c}-79.3 \\
(-89.1 \text { to }-69.5)\end{array}$ & $\begin{array}{c}-72.4 \\
(-87.4 \text { to }-57.5)\end{array}$ & $\begin{array}{c}-79.2 \\
(-90.1 \text { to }-68.4)\end{array}$ & $\begin{array}{c}-75.3 \\
(-85.2 \text { to }-65.4)\end{array}$ & $\begin{array}{c}-73.6 \\
(-88.8 \text { to }-58.3)\end{array}$ & $\begin{array}{c}-82.1 \\
(-93.0 \text { to }-71.2)\end{array}$ & $\begin{array}{c}-73.4 \\
(-85.4 \text { to }-61.4)\end{array}$ & $\begin{array}{c}-75.6 \\
(-92.7 \text { to }-58.4)\end{array}$ & $\begin{array}{c}-75.6 \\
(-89.3 \text { to }-61.8)\end{array}$ \\
\hline
\end{tabular}

Model I: Univariable model with FTO rs9939609 genotype as single fixed effect. Model II: Multivariable model with FTO rs9939609 genotype as a fixed effect and sex, age, fat mass and visceral adipose tissue as covariates. Model III: Multivariable model with FTO rs9939609 genotype as a fixed effect and sex, age, body mass index, peak oxygen uptake, resting metabolic rate, visceral adipose tissue, abdominal subcutaneous adipose tissue, liver fat, sitting time and moderate-to-vigorous physical activity as covariates.

Values are mean (95\% confidence interval (CI)). Eta ${ }^{2}, 90 \%$ CI and $P$-values are from the fixed effect of the FTO rs9939609 genotype group. 


\section{Sex-specific Pearson's correlation coefficients}

\section{Appetite-related outcomes and individual characteristics}

No significant correlations were observed between fasting acylated ghrelin and age, BMI, fat mass, $\dot{\mathrm{VO}}_{2}$ peak, resting metabolic rate, visceral fat, abdominal subcutaneous adipose tissue, liver fat, average sitting or average MVPA in men ( $\mathrm{r}=-0.18$ to $0.07, \mathrm{P} \geq 0.185)$ or women $(\mathrm{r}=$ -0.19 to $0.06, P \geq 0.175)$. Similarly, no significant correlations were observed between fasting total PYY and any of the individual characteristics in men $(r=-0.13$ to $0.14, \mathrm{P} \geq 0.330)$ or women $(\mathrm{r}=-0.14$ to $0.10, \mathrm{P} \geq 0.323$ ). Pearson's correlation coefficients between individual characteristics and fasting insulin, glucose and leptin are presented in Table 4. In summary, fasting insulin was positively correlated with general and abdominal adiposity parameters in both sexes and with liver fat in men $(\mathrm{r}=0.32$ to $0.53, \mathrm{P} \leq 0.010)$. Fasting insulin was negatively correlated with $\dot{\mathrm{VO}}_{2}$ peak in both sexes and with MVPA in men $(\mathrm{r}=-0.35$ to $-0.47, \mathrm{P} \leq 0.004)$. Fasting glucose was positively correlated with total and abdominal adiposity parameters in both sexes, with age and liver fat in men, and with resting metabolic rate in women $(r=0.28$ to 0.44 , $\mathrm{P} \leq 0.017)$. Fasting glucose was negatively correlated with $\dot{\mathrm{VO}}_{2}$ peak in both sexes $(\mathrm{r}=-0.29$ to $-0.28, \mathrm{P} \leq 0.020)$. Fasting leptin was positively correlated with general and abdominal adiposity parameters in both sexes, and with age and liver fat in men $(r=0.24$ to $0.83, \mathrm{P} \leq 0.040)$. Fasting leptin was negatively correlated with $\dot{\mathrm{VO}}_{2}$ peak in both sexes and with MVPA in men $(\mathrm{r}=-0.35$ to $-0.64, \mathrm{P} \leq 0.006)$. In men, fasting overall appetite was negatively associated with fat mass ( $\mathrm{r}$ $=-0.31, \mathrm{P}=0.022,95 \% \mathrm{CI}=-0.53$ to -0.05$)$ and abdominal subcutaneous adipose tissue $(\mathrm{r}=$ $0.30, \mathrm{P}=0.032,95 \% \mathrm{CI}=-0.53$ to -0.02 ). No significant correlations between fasting overall appetite and individual characteristics were observed in women $(\mathrm{r}=-0.12$ to $0.09, \mathrm{P} \geq 0.391)$.

Delta AUC for acylated ghrelin was positively associated with sitting time $(\mathrm{r}=0.29, P=0.048$, $95 \% \mathrm{CI}=0.00$ to 0.53$)$ and negatively associated with age $(\mathrm{r}=-0.32, P=0.017,95 \% \mathrm{CI}=-0.54$ to -0.06$)$ in men. Insulin AUC was positively associated with visceral adipose tissue in men $(\mathrm{r}=$ $0.38, P=0.007,95 \% \mathrm{CI}=0.11$ to 0.59$)$ and women $(\mathrm{r}=0.32, P=0.021,95 \% \mathrm{CI}=0.05$ to 0.55$)$, and with fat mass ( $\mathrm{r}=0.39, P=0.003,95 \% \mathrm{CI}=0.14$ to 0.59$)$, abdominal subcutaneous adipose tissue $(\mathrm{r}=0.31, P=0.026,95 \% \mathrm{CI}=0.03$ to 0.54$)$ and liver fat $(\mathrm{r}=0.47, P=0.001,95 \% \mathrm{CI}=$ 0.21 to 0.66$)$ in men. Insulin AUC was negatively associated with $\dot{\mathrm{VO}}_{2}$ peak $(\mathrm{r}=-0.44, P=0.001$, $95 \% \mathrm{CI}=-0.63$ to -0.20$)$ and MVPA ( $\mathrm{r}=-0.38, P=0.007,95 \% \mathrm{CI}=-0.60$ to -0.11$)$ in men. None of the correlations between AUC for total PYY, glucose and overall appetite and individual characteristics were statistically significant ( $\mathrm{r}=-0.23$ to $0.24, \mathrm{P} \geq 0.061$ ). 
Table 4. Sex-specific Pearson's correlation coefficients between fasting appetite-related blood markers and individual characteristics.

\begin{tabular}{|c|c|c|c|}
\hline & Fasting insulin $\left(\mathrm{pmol} \cdot \mathrm{L}^{-1}\right)$ & Fasting glucose $\left(\mathrm{mmol} \cdot \mathrm{L}^{-1}\right)$ & Fasting leptin $\left(\mathrm{ng} \cdot \mathrm{mL}^{-1}\right)$ \\
\hline \multirow[t]{2}{*}{ Age (years) } & Men: $\mathrm{r}=-0.01, P=0.457,95 \% \mathrm{CI}=-0.27$ to 0.25 & Men: $r=0.34, P=0.005,95 \% \mathrm{CI}=0.08$ to 0.55 & Men: $r=0.24, P=0.040,95 \% C I=-0.02$ to 0.47 \\
\hline & Women: $\mathrm{r}=-0.16, P=0.123,95 \% \mathrm{CI}=-0.40$ to 0.11 & Women: $\mathrm{r}=0.08, P=0.270,95 \% \mathrm{CI}=-0.19$ to 0.33 & Women: $\mathrm{r}=-0.07, P=0.298,95 \% \mathrm{CI}=-0.33$ to 0.20 \\
\hline \multirow{2}{*}{$\begin{array}{l}\text { Body mass index } \\
\left(\mathrm{kg} \cdot \mathrm{m}^{-2}\right)\end{array}$} & Men: $r=0.39, P=0.003,95 \% C I=0.14$ to 0.59 & Men: $r=0.33, P=0.013,95 \% C I=0.07$ to 0.54 & Men: $r=0.62, P<0.001,95 \% C I=0.43$ to 0.76 \\
\hline & Women: $r=0.53, P<0.001,95 \% \mathrm{CI}=0.31$ to 0.69 & Women: $r=0.35, P=0.004,95 \% C I=0.10$ to 0.56 & 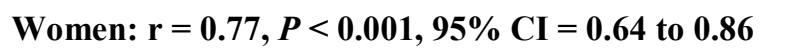 \\
\hline \multirow[t]{2}{*}{ Fat mass $(\mathrm{kg})$} & Men: $r=0.49, P<0.001,95 \% C I=0.26$ to 0.67 & Men: $r=0.44, P<0.001,95 \% C I=0.20$ to 0.63 & Men: $r=0.83, P<0.001,95 \% C I=0.73$ to 0.90 \\
\hline & Women: $r=0.32, P=0.008,95 \% C I=0.06$ to 0.54 & Women: $r=0.28, P=0.017,95 \% C I=0.02$ to 0.50 & Women: $\mathrm{r}=\mathbf{0 . 7 5}, P<0.001,95 \% \mathrm{CI}=\mathbf{0 . 6 1}$ to 0.85 \\
\hline \multirow{2}{*}{$\begin{array}{l}\dot{\mathrm{VO}_{2}} \text { peak } \\
\left(\mathrm{mL} \cdot \mathrm{kg} \cdot \mathrm{min}^{-1}\right)\end{array}$} & Men: $r=-0.47, P<0.001,95 \% C I=-0.65$ to -0.24 & Men: $r=-0.29, P=0.015,95 \% C I=-0.51$ to -0.03 & Men: $r=-0.64, P<0.001,95 \% C I=-0.77$ to -0.45 \\
\hline & Women: $\mathrm{r}=-\mathbf{0 . 3 5}, P=\mathbf{0 . 0 0 4}, 95 \% \mathrm{CI}=-\mathbf{0 . 5 6}$ to -0.10 & Women: $\mathrm{r}=-\mathbf{0 . 2 8}, P=0.020,95 \% \mathrm{CI}=-\mathbf{0 . 5 0}$ to -0.02 & Women: $r=-0.58, P<0.001,95 \% C I=-0.73$ to -0.37 \\
\hline \multirow{2}{*}{$\begin{array}{l}\text { Resting metabolic } \\
\text { rate (kcal) }\end{array}$} & Men: $\mathrm{r}=-0.04, P=0.381,95 \% \mathrm{CI}=-0.31$ to 0.23 & Men: $\mathrm{r}=-0.12, P=0.205,95 \% \mathrm{CI}=-0.38$ to 0.15 & Men: $\mathrm{r}=0.05, P=0.369,95 \% \mathrm{CI}=-0.22$ to 0.32 \\
\hline & Women: $\mathrm{r}=0.03, P=0.402,95 \% \mathrm{CI}=-0.24$ to 0.29 & Women: $\mathrm{r}=\mathbf{0 . 3 5}, P=\mathbf{0 . 0 0 5}, 95 \% \mathrm{CI}=\mathbf{0 . 0 9}$ to 0.56 & Women: $\mathrm{r}=0.05, P=0.359,95 \% \mathrm{CI}=-0.22$ to 0.31 \\
\hline \multirow{2}{*}{$\begin{array}{l}\text { Visceral adipose } \\
\text { tissue (L) }\end{array}$} & Men: $r=0.41, P=0.002,95 \% C I=0.15$ to 0.62 & Men: $r=0.42, P=0.001,95 \% \mathrm{CI}=0.15$ to 0.63 & Men: $r=0.65, P<0.001,95 \% C I=0.45$ to 0.79 \\
\hline & Women: $r=0.33, P=0.010,95 \% C I=0.06$ to 0.55 & Women: $r=0.36, P=0.005,95 \% C I=0.09$ to 0.58 & Women: $\mathrm{r}=0.62, P<0.001,95 \% \mathrm{CI}=0.42$ to 0.76 \\
\hline \multirow{2}{*}{$\begin{array}{l}\text { Abdominal } \\
\text { subcutaneous } \\
\text { adipose tissue (L) }\end{array}$} & Men: $r=0.43, P=0.002,95 \% C I=0.17$ to 0.63 & Men: $r=0.39, P=0.005,95 \% C I=0.13$ to 0.60 & Men: $r=0.79, P<0.001,95 \% C I=0.66$ to 0.87 \\
\hline & Women: $r=0.44, P=0.001,95 \% C I=0.19$ to 0.64 & Women: $\mathrm{r}=0.34, P=0.013,95 \% \mathrm{CI}=0.07$ to 0.56 & Women: $\mathrm{r}=0.79, \mathrm{P}<0.001,95 \% \mathrm{CI}=0.66$ to 0.87 \\
\hline \multirow[t]{2}{*}{ Liver fat $(\%)$} & Men: $r=0.49, P<0.001,95 \% C I=0.24$ to 0.68 & Men: $r=0.33, P=0.010,95 \% C I=0.05$ to 0.56 & Men: $r=0.44, P=0.001,95 \% C I=0.18$ to 0.64 \\
\hline & Women: $\mathrm{r}=0.06, P=0.338,95 \% \mathrm{CI}=-0.22$ to 0.33 & Women: $\mathrm{r}=0.07, P=0.305,95 \% \mathrm{CI}=-0.21$ to 0.34 & Women: $\mathrm{r}=0.18, P=0.112,95 \% \mathrm{CI}=-0.11$ to 0.44 \\
\hline \multirow{2}{*}{$\begin{array}{l}\text { Average sitting } \\
\text { time }\left(\mathrm{min} \cdot \mathrm{day}^{-1}\right)\end{array}$} & Men: $\mathrm{r}=-0.06, P=0.340,95 \% \mathrm{CI}=-0.34$ to 0.23 & Men: $\mathrm{r}=-0.12, P=0.210,95 \% \mathrm{CI}=-0.39$ to 0.17 & Men: $\mathrm{r}=-0.12, P=0.207,95 \% \mathrm{CI}=-0.39$ to 0.17 \\
\hline & Women: $\mathrm{r}=0.12, P=0.196,95 \% \mathrm{CI}=-0.17$ to 0.39 & Women: $\mathrm{r}=0.13, P=0.190,95 \% \mathrm{CI}=-0.16$ to 0.40 & Women: $\mathrm{r}=0.05, P=0.353,95 \% \mathrm{CI}=-0.23$ to 0.33 \\
\hline \multirow{2}{*}{$\begin{array}{l}\text { Average MVPA } \\
\text { time }\left(\min \cdot \text { day }^{-1}\right)\end{array}$} & Men: $r=-0.44, P=0.001,95 \% C I=-0.64$ to -0.18 & Men: $r=-0.03, P=0.420,95 \% \mathrm{CI}=-0.31$ to 0.25 & Men: $r=-0.35, P=0.006,95 \% \mathrm{CI}=-\mathbf{0 . 5 7}$ to -0.08 \\
\hline & Women: $\mathrm{r}=-0.01, P=0.493,95 \% \mathrm{CI}=-0.28$ to 0.27 & Women: $\mathrm{r}=0.09, P=0.274,95 \% \mathrm{CI}=-0.19$ to 0.36 & Women: $\mathrm{r}=-0.10, P=0.241,95 \% \mathrm{CI}=-0.36$ to 0.18 \\
\hline
\end{tabular}

AUC, area under the curve; FTO, fat mass and obesity associated gene; MVPA, moderate-to-vigorous physical activity, PYY, peptide YY; $\dot{V}_{2}$ peak, peak oxygen uptake. 
359 Fasting overall appetite was negatively associated with fasting insulin $(\mathrm{r}=-0.32, \mathrm{P}=0.015,95 \%$ $360 \mathrm{CI}=-0.54$ to -0.06$)$ and fasting leptin $(\mathrm{r}=-0.35, \mathrm{P}=0.008,95 \% \mathrm{CI}=-0.56$ to -0.10$)$ in men. 361 Delta AUC for overall appetite was positively associated with insulin AUC $(r=0.35, P=0.009$, $36295 \% \mathrm{CI}=0.10$ to 0.56 ) in women. No other significant correlations between overall appetite and 363 appetite-related blood parameters were evident in the fasted or postprandial state $(r=-0.20$ to $3640.26, P \geq 0.052$ ).

\section{DISCUSSION}

367 The primary finding of this study is that very little influence of the FTO rs9939609 genotype 368 was identified for fasting and postprandial perceived appetite and appetite-related blood outcomes in healthy men and women. Explained variance for FTO group on all outcomes was small $(<5 \%)$ according to the thresholds suggested by Cohen (1998). Even the upper $90 \%$ confidence limits of the explained variance were low for each outcome $(<15 \%)$. In the context of precision medicine, we maintain that explained variance would need to be much larger than our observed values for the FTO rs9939609 gene to be a useful predictor of appetite-related outcomes. We also found that fasting and postprandial acylated ghrelin and total PYY were not associated with general or abdominal adiposity, while leptin, glucose and insulin concentrations were consistently associated with adiposity variables. Our study is the first to employ an integrative approach to investigate associations between a variety of genetic, physiological and lifestyle characteristics with appetite-related outcomes. Previous research has provided limited evidence on the influence of specific individual characteristics on appetite-related blood parameters and appetite perceptions.

The FTO gene represents the most extensively-studied gene that has been associated with a higher risk of obesity (Frayling et al. 2007), yet evidence on the physiological mechanisms involved is limited. The study undertaken by Karra et al. (2013) supported the hypothesis that satiety control differs between FTO rs9939609 genotype groups. Specifically, the group with higher obesity risk (AA) presented attenuated suppression of acylated ghrelin and perceived hunger after consumption of a meal, which can naturally lead to higher energy intake and, consequently, higher body mass (Karra et al. 2013). However, our results do not support this hypothesis as we found very little influence of genotype group on acylated ghrelin concentrations or perceived appetite ratings. Differences between study samples can possibly explain 
discrepancies between findings, as Karra et al. (2013) recruited healthy young lean males, while our sample was composed of a heterogeneous group of males and females. Additionally, Karra et al. (2013) selectively sampled their participants in order to match groups for certain variables, 393 whereas we adopted a multivariate-adjusted approach to our data analysis. Interestingly, recent studies have reported lower postprandial total ghrelin concentrations in AA compared to AT and TT individuals (Magno et al. 2018; Melhorn et al. 2018), and postprandial hunger ratings were either similar between genotype groups (Melhorn et al. 2018) or were lower in AA individuals (Magno et al. 2018). These findings were observed despite the AA individuals exhibiting higher energy intake during an ad libitum buffet (Melhorn et al. 2018). Of note, the active part of ghrelin (acylated ghrelin) only represents approximately 5 to 10\% of total ghrelin (Hosoda et al, 2000; Yoshimoto et al. 2002) and, therefore, the assessment of total ghrelin in these studies could potentially explain the variability in findings.

402 Our research group has recently conducted a replicated crossover study to examine individual 403 appetite responses to meal intake in healthy men recruited according to their FTO rs9939609 404 genotype (AA or TT) (Goltz et al. 2019). The findings from this study highlighted the existence 405 of interindividual variability in perceived appetite and acylated ghrelin, total PYY, insulin and 406 glucose responses to a standardised meal over and above any measurement errors and/or natural 407 variance of the outcomes. However, the magnitude of postprandial appetite parameter responses 408 after meal intake was not influenced by the FTO rs9939609 gene (Goltz et al. 2019). In line with 409 our findings, previous studies have reported no differences between FTO rs9939609 genotype 410 groups for fasting glucose and insulin (Speakman et al. 2008), fasting leptin (Speakman et al. 411 2008; Karra et al. 2013; Melhorn et al. 2018), fasting and postprandial PYY3-36 (Karra et al. 2013) 412 and fasting and postprandial GLP-1 (Melhorn et al. 2018). Beyond the subjective appetite and 413 appetite-related blood outcomes assessed in this study, AA and TT individuals have been shown 414 to exhibit divergent neural responsiveness to food cues within homeostatic and reward brain 415 regions in both fasted and postprandial states (Karra et al. 2013). Specifically, AA individuals 416 rated high-energy food images as more appealing than TT individuals, and positive associations 417 between circulating acylated ghrelin and central neural system responsiveness to food cues were 418 observed only in TT individuals (Karra et al. 2013). Moreover, recent evidence suggests that AA 419 individuals show higher total food cravings, compared to TT individuals, which correlated with 420 BMI (Dang et al. 2018). Additional studies are needed to elucidate the precise role that FTO 421 rs9939609 plays in moderating appetite control and energy intake which include both central and peripheral factors implicated in appetite regulation. 
Although evidence to date suggests a negligible impact of FTO rs9939609 genotype on energy expenditure, higher levels of physical activity seem to exert a protective effect on the obesity risk associated with FTO (Sonestedt et al. 2009; Speakman, 2015). On the contrary, diets with higher fat content can exacerbate the susceptibility to obesity linked to the FTO rs9939609 high-risk genotype (Sonestedt et al. 2009; Speakman, 2015). Our study included objectively assessed sitting time, MVPA and cardiorespiratory fitness as covariates in the statistical analyses. However, only $20 \%$ of our participants accumulated, on average, less than 30 min of MVPA per day, indicating that most participants in our sample had relatively high levels of physical activity. Therefore, we cannot rule out the possibility of this hindering our ability to detect differences in appetite-related outcomes between the genotype groups (Speakman et al. 2008). Our study did not include any assessment of habitual dietary intake and, therefore, fat intake was not taken into consideration in our analyses. Nevertheless, it is well known that the currently available dietary intake assessment tools do not provide reliable data, and this currently represents a major challenge for those involved in nutrition-related research, clinical practice or policy development (Dhurandhar et al. 2015; Archer et al. 2018).

In contrast to previous studies (Alajmi et al. 2016; Douglas et al. 2017), we did not observe a statistically significant difference in fasting concentrations of acylated ghrelin between men and women. The reason for this disparity is unclear but it is worth noting that two female participants were identified as clear outliers within our sample, with fasting acylated ghrelin concentrations of 2,899 and 4,411 $\mathrm{pg} \cdot \mathrm{mL}^{-1}$. These extremely high concentrations of acylated ghrelin were observed consistently in all four samples collected for each participant, indicating these values represented physiological characteristics of these two individuals rather than merely one-off measurement errors. Further studies are needed to investigate potential causes and consequences of such extreme concentrations of acylated ghrelin, and care should be taken when interpreting group mean results, as group means can be greatly impacted by such outliers. Nevertheless, exclusion of the outliers did not influence any of the statistical models in this study and, therefore, data are presented with the outliers included. Higher concentrations of fasting glucose were observed in men than women in the current study, which may be indicative of a greater degree of insulin resistance resulting from the higher visceral adipose tissue and liver fat levels observed in men (Marchesini et al, 2001; Ibrahim, 2010). Higher levels of fasting leptin were observed in women, likely because of the higher fat mass values in relation to total body mass in women, compared to men (Marshall et al. 2000; Rosenbaum and Leibel, 2014). 
After meal consumption, greater changes in acylated ghrelin and overall appetite were observed in women than men. It should be noted that all participants received an identical standardised meal and, as women had significantly lower body mass and fat free mass, and consequently lower resting metabolic rate, it was expected that the postprandial suppression of appetite would be stronger in women. However, it is interesting to observe that, apart from acylated ghrelin, no other statistically significant differences were observed between men and women in any of the remaining postprandial appetite-related blood parameters. Previous evidence has demonstrated a stronger suppression of acylated ghrelin in women than men after acute exercise and standardised meals (Douglas et al. 2017), but not after the consumption of a standardised liquid meal (Carroll et al. 2007).

Our exploratory analyses did not identify any statistically significant or meaningful association between adiposity parameters and fasting or postprandial concentrations of acylated ghrelin and total PYY. This is in contrast with findings from previous studies which demonstrated a lower postprandial suppression of total and acylated ghrelin (Le Roux et al. 2005; Carrol et al. 2007) and a blunted postprandial elevation in PYY (Le Roux et al. 2006) in individuals with obesity. However, as expected, fasting insulin, glucose and leptin and postprandial insulin were all positively associated with general and visceral adiposity, demonstrated by moderate to very large correlation coefficients, which is consistent with the well-established role of leptin in signalling adiposity levels (Rosenbaum and Leibel, 2014) and the impact of adiposity on insulin resistance (Ibrahim, 2010). Additionally, fat free mass, which represents the largest determinant of resting metabolic rate, has been identified as a primary determinant of appetite and energy intake (Blundell et al. 2015b). However, our findings did not reveal any significant associations of appetite-related hormones or perceived appetite with resting metabolic rate.

While acute bouts of exercise have been shown consistently to transiently suppress appetite (King et al. 2017), chronic exercise and high levels of physical activity have been suggested to increase the overall drive to eat and, concomitantly, to increase the satiating effect of a standardised meal (King et al. 2009; Beaulieu et al. 2016). We did not identify any significant associations between habitual physical activity levels and fasting or postprandial acylated ghrelin, total PYY, glucose or perceived appetite. However, a negative association was observed between MVPA and fasting leptin and insulin, and postprandial insulin in men. Additionally, negative associations between $\dot{\mathrm{VO}}_{2}$ peak and fasting and postprandial insulin, fasting glucose and fasting leptin were observed. Acute and chronic exercise augments insulin sensitivity by increasing insulin-like growth factor 
1, and individuals with higher cardiorespiratory fitness typically show higher insulin sensitivity (Borghouts and Keizer, 2000; Castro et el. 2016). Furthermore, a recent meta-analysis showed that leptin concentrations can be reduced by exercise in individuals who are overweight even in the absence of dietary interventions or major weight loss (BMI reduction of $>2.5 \%$ ) (Rostás et al. 2017). Postprandial acylated ghrelin was positively associated with sitting time in men, but this correlation was small in magnitude and would not be considered significant if the stricter threshold of $\mathrm{P}<0.005$ was applied in line with recent recommendations (Benjamin et al. 2017).

Perceived fasting overall appetite was negatively associated with total fat mass in men supporting previous evidence suggesting the existence of negative feedback signals originating from fat mass in order to regulate appetite and maintain body weight (Weise et al. 2014; Blundell et al. 2015a). However, no association was observed between postprandial perceived appetite and any adiposity parameter in our study. Interestingly, no statistically significant associations between fasting or postprandial perceived overall appetite and acylated ghrelin or total PYY were identified. Even though circulating concentrations of acylated ghrelin and PYY vary on a mealto-meal basis, concomitantly with perceived appetite, the magnitude and direction of the changes in hormone concentrations are not always mirrored by changes in perceived appetite (Goltz et al. 2018). In contrast, postprandial overall appetite AUC was positively associated with postprandial insulin AUC in women, which is consistent with previous findings showing that postprandial insulin concentrations are positively associated with postprandial satiety and negatively associated with postprandial hunger (Flint et al. 2007).

The strengths of our study include the use of an integrative approach and objective assessment methods to explore the associations of the FTO rs9939609 genotype with fasting and postprandial appetite-related hormones and perceived appetite, taking into consideration a variety of individual characteristics that have been previously suggested to influence appetite parameters. Furthermore, the recruitment of a highly heterogeneous sample for parameters such as age, adiposity and cardiorespiratory fitness levels adds strength to our analyses. Finally, the careful standardisation of diet and physical activity in the $24 \mathrm{~h}$ preceding the laboratory visit, as well as the inclusion of a cannula acclimatisation period, also contributed to the quality of the study outcome measurements obtained. However, it should be highlighted that our study employed an exploratory approach and the cross-sectional design makes it impossible to imply any causation in our results. Our results may have been compromised by the reduced sample size and by the loss of power in some of the statistical models due to missing data. Additionally, it is possible 
519 that a study design where individuals are exposed to an obesigenic food environment, such as an

520 ad libitum buffet meal rather than a standardised meal stimulus, may be more appropriate to 521 elucidate the effect of FTO rs9939609 genotype on food choice and eating behaviour. 522 Furthermore, participants were aware of the meal timing so it is possible that the higher preprandial ghrelin concentrations reflected an anticipatory response to impending meal intake

524 (Cummings et al. 2001). Future studies should consider isolating meal provision from time525 related cues and/or examining the influence of cephalic phase ghrelin release during meal 526 anticipation on postprandial appetite responses.

527 In conclusion, the FTO rs9939609 genotype did not have any significant influence on fasting or 528 postprandial perceived appetite or appetite-related blood parameters in healthy men and women. 529 The associations between fasting and postprandial acylated ghrelin, total PYY and general or 530 abdominal adiposity were also small, while fasting leptin, glucose and insulin and postprandial 531 insulin concentrations were consistently and positively associated with adiposity outcomes. 532 Further research is needed to clarify the precise role of the FTO rs9939609 genotype in 533 moderating appetite control and energy intake, including both physiological and psychological 534 factors that influence eating behaviour. Specifically, well-controlled long-term studies are 535 needed to improve understanding of the effect of the FTO rs9939609 genotype on appetite and 536 energy intake during and after interventions targeting weight loss and/or prevention of weight 537 gain. Understanding the complex interaction between genetics and other individual 538 characteristics, physiological appetite parameters and perceived appetite is of crucial importance 539 for planning targeted strategies for weight control.

\section{ACKNOWLEDGEMENTS}

542 This research was funded by the NIHR Leicester Biomedical Research Centre. The views 543 expressed are those of the author(s) and not necessarily those of the NHS, the NIHR or the 544 Department of Health and Social Care.

\section{REFERENCES}

547 Alajmi N, Deighton K, King JA, Reischak-Oliveira A, Wasse LK, Jones J, et al. Appetite and 548 energy intake responses to acute energy deficits in females versus males. Med Sci Sports 549 Exerc. 2016;48(3):412-20. 
550 Archer E, Lavie CJ, Hill JO. The failure to measure dietary intake engendered a fictional 551 discourse on diet-disease relations. Front Nutr. 2018;5:105.

552 Atkin AJ, Gorely T, Clemes SA, Yates T, Edwardson C, Brage S, et al. Methods of 553 measurement in epidemiology: sedentary behaviour. Int J Epidemiol. 2012;41(5):1460-71.

554 Atkinson G, Batterham AM. True and false interindividual differences in the physiological 555 response to an intervention. Exp Physiol 2015;100(6):577-88.

556 Beaulieu K, Hopkins M, Blundell J, Finlayson G. Does habitual physical activity increase the 557 sensitivity of the appetite control system? A systematic review. Sports Med. 2016;46(12):1897558919.

559 Benjamin DJ, Berger J, Johannesson M, Nosek BA, Wagenmakers E, Berk R, et al. Redefine 560 statistical significance. PsyArXiv (online). 2017. Available at: 561 https://doi.org/10.31234/osf.io/mky9j (Accessed on: January 11, 2019).

562 Bland JM, Altman DG. Transforming data. BMJ. 1996;23;312(7033):770.

563 Blundell JE, Finlayson G, Gibbons C, Caudwell P, Hopkins M. The biology of appetite control: 564 Do resting metabolic rate and fat-free mass drive energy intake? Physiol Behav. 2015;152(Pt 565 B):473-8.

566 Blundell JE, Gibbons C, Caudwell P, Finlayson G, Hopkins M. Appetite control and energy 567 balance: impact of exercise. Obes Rev. 2015;16 Suppl 1:67-76.

568 Blundell JE, Levin F, King NA, Barkeling B, Gustafsson T, Hellstrom PM, et al. 569 Overconsumption and obesity: peptides and susceptibility to weight gain. Regul 570 Pept. 2008;149(1-3):32-8.

571 Borg GA. Perceived exertion. A note on "history" and methods. Med Sci Sports. 1973;5(2):905723.

573 Borga M, Thomas EL, Romu T, Rosander J, Fitzpatrick J, Dahlqvist Leinhard O, et al. 574 Validation of a fast method for quantification of intra-abdominal and subcutaneous adipose 575 tissue for large-scale human studies. NMR Biomed. 2015;28(12):1747-53.

576 Borghouts LB, Keizer HA. Exercise and insulin sensitivity: a review. Int J Sports 577 Med. 2000;21(1):1-12. 
578 Carroll JF, Kaiser KA, Franks SF, Deere C, Caffrey JL. Influence of BMI and gender 579 on postprandial hormone responses. Obesity. 2007;15(12):2974-83.

580 Castro MG, Venutolo C, Yau PL, Convit A. Fitness, insulin sensitivity, and frontal lobe integrity 581 in adults with overweight and obesity. Obesity. 2016;24(6):1283-9.

582 Chandarana K, Drew ME, Emmanuel J, Karra E, Gelegen C, Chan P, et al. Subject 583 standardization, acclimatization, and sample processing affect gut hormone levels and appetite 584 in humans. Gastroenterology. 2009;136(7):2115-26.

585 Cohen J. Statistical power analysis for the behavioral sciences. 1988. 2nd ed. Hillsdale, NJ: 586 Lawrence Erlbaum Associates.

587 Cummings DE, Purnell JQ, Frayo RS, Schmidova K, Wisse BE, Weigle DS. A preprandial rise 588 in plasma ghrelin levels suggests a role in meal initiation in humans. Diabetes. 2001;50(8):17145899.

590 Dang LC, Samanez-Larkin GR, Smith CT, Castrellon JJ, Perkins SF, Cowan RL, et al. 591 FTO affects food cravings and interacts with age to influence age-related decline in food 592 cravings. Physiol Behav. 2018;192:188-93.

593 Deighton K, Batterham RL, Stensel DJ. Appetite and gut peptide responses to exercise and 594 calorie restriction. The effect of modest energy deficits. Appetite. 2014;81:52-9.

595 Deighton K, Karra E, Batterham RL, Stensel DJ. Appetite, energy intake, and PYY 3 59636 responses to energy-matched continuous exercise and submaximal high-intensity exercise.

597 Appl Physiol Nutr Metab. 2013;38(9):947-52

598 Dill DB, Costill DL. Calculation of percentage changes in volumes of blood, plasma, and red 599 cells in dehydration. J Appl Physiol. 1974;37:247-8.

600 Douglas JA, King JA, Clayton DJ, Jackson AP, Sargeant JA, Thackray AE, et al. Acute effects 601 of exercise on appetite, ad libitum energy intake and appetite-regulatory hormones in lean and 602 overweight/obese men and women. Int J Obes. 2017;41(12):1737-44.

603 Dhurandhar NV, Schoeller D, Brown AW, Heymsfield SB, Thomas D, Sørensen TI, et al. 604 Energy balance measurement: when something is not better than nothing. Int J Obes. $605 \quad 2015 ; 39(7): 1109-13$. 
606 Flint A, Gregersen NT, Gluud LL, Møller BK, Raben A, Tetens I, et al. Associations between 607 postprandial insulin and blood glucose responses, appetite sensations and energy intake in 608 normal weight and overweight individuals: a meta-analysis of test meal studies. Br J 609 Nutr 2007;98(1):17-25.

610 Flint A, Raben A, Blundell JE, Astrup A. Reproducibility, power and validity of visual analogue 611 scales in assessment of appetite sensations in single test meal studies. Int J Obes. 2000;24(1):3861248.

613 Flom P, Cassell D. Stopping stepwise: Why stepwise and similar selection methods are bad, and 614 what you should use. NESUG 2007 Proceedings: Statistics and data analysis.

615 Frayling TM, Timpson NJ, Weedon MN, Zeggini E, Freathy RM, Lindgren CM, et al. A 616 common variant in the FTO gene is associated with body mass index and predisposes to 617 childhood and adult obesity. Science. 2007;316(5826):889-94.

618 Gelman A, Pardoe I. Average predictive comparisons for models with nonlinearity, interactions, 619 and variance components. Sociol Methodol. 2007;37(1):23-51.

620 Goltz FR, Thackray AE, Atkinson G, Lolli L, King JA, Dorling JL, et al. True interindividual 621 variability exists in postprandial appetite responses in healthy men but is not moderated by the 622 FTO genotype. J Nutr. 2019 [in press].

623 Goltz FR, Thackray AE, King JA, Dorling JL, Atkinson G, Stensel DJ. Interindividual 624 responses of appetite to acute exercise: a replicated crossover study. Med Sci Sports 625 Exerc. 2018;50(4):758-68.

626 Hosoda H, Kojima M, Matsuo H, Kangawa K. Ghrelin and des-acyl ghrelin: two major forms of 627 rat ghrelin peptide in gastrointestinal tissue. Biochem Biophys Res Commun 2000;279(3):90962813

629 Ibrahim MM. Subcutaneous and visceral adipose tissue: structural and functional differences. 630 Obes Rev. 2010;11(1):11-8.

631 Jackson AS, Pollock ML, Ward A. Generalized equations for predicting body density of women. 632 Med Sci Sports Exerc.1980;12(3):175-81. 
633 Jackson AS, Pollock ML. Generalized equations for predicting body density of men. Br J Nutr. 634 1978;40(3):497-504.

635 Karra E, O'Daly OG, Choudhury AI, Yousseif A, Millership S, Neary MT, et al. A link between 636 FTO, ghrelin, and impaired brain food-cue responsivity. J Clin Invest. 2013;123(8):3539-51.

637 King JA, Deighton K, Broom DR, Wasse LK, Douglas JA, Burns SF, et al. 638 Individual variation in hunger, energy intake, and ghrelin responses to acute exercise. Med Sci 639 Sports Exerc. 2017;49(6):1219-28.

640 King NA, Caudwell PP, Hopkins M, Stubbs JR, Naslund E, Blundell JE. Dual-process action of 641 exercise on appetite control: increase in orexigenic drive but improvement in meal-induced 642 satiety. Am J Clin Nutr. 2009;90(4):921-7.

643 Kline RB. Beyond significance testing: Reforming data analysis methods in behavioral 644 research. 2004. Washington, DC: American Psychological Association.

645 Kozey-Keadle S, Libertine A, Lyden K, Staudenmayer, J, Freedson, PS. Validation of wearable 646 monitors for assessing sedentary behavior. Med Sci Sports Exerc. 2011;43(8):1561-7.

647 Le Roux CW, Batterham RL, Aylwin SJ, Patterson M, Borg CM, Wynne KJ, et al. Attenuated 648 peptide YY release in obese subjects is associated with reduced satiety. 649 Endocrinology. 2006;147(1):3-8.

650 Le Roux CW, Patterson M, Vincent RP, Hunt C, Ghatei MA, Bloom SR. Postprandial plasma 651 ghrelin is suppressed proportional to meal calorie content in normal-weight but not obese 652 subjects. J Clin Endocrinol Metab. 2005;90(2):1068-71.

653 MacLean PS, Blundell JE, Mennella JA, Batterham RL. Biological control of appetite: A 654 daunting complexity. Obesity (Silver Spring). 2017;25;Suppl 1:S8-S16.

655 Magno FCCM, Guaraná HC, Fonseca ACP, Cabello GMK, Carneiro JRI, Pedrosa AP, et al. 656 Influence of FTO rs9939609 polymorphism on appetite, ghrelin, leptin, IL6, TNF $\alpha$ levels, and 657 food intake of women with morbid obesity. Diabetes Metab Syndr Obes. 2018;11:199-207.

658 Marchesini G, Brizi M, Bianchi G, Tomassetti S, Bugianesi E, Lenzi M, et al. Nonalcoholic 659 fatty liver disease: a feature of the metabolic syndrome. Diabetes. 2001;50(8):1844-50. 
660 Marshall JA, Grunwald GK, Donahoo WT, Scarbro S, Shetterly SM. Percent body fat and lean 661 mass explain the gender difference in leptin: analysis and interpretation of leptin in hispanic and 662 non-hispanic white adults. Obes Res. 2000;8(8):543-52.

663 Melhorn SJ, Askren MK, Chung WK, Kratz M, Bosch TA, Tyagi V, et al. FTO genotype 664 impacts food intake and corticolimbic activation. Am J Clin Nutr. 2018;107(2):145-54.

665 Neary MT, Batterham RL. Gut hormones: implications for the treatment of obesity. Pharmacol 666 Ther. 2009;124(1):44-56.

667 Rosenbaum M, Leibel RL. Role of leptin in energy homeostasis in humans. J 668 Endocrinol. 2014;223(1):T83-96.

669 Rostás I, Pótó L, Mátrai P, Hegyi P, Tenk J, Garami A, et al. In middle-aged and old obese 670 patients, training intervention reduces leptin level: A meta-analysis. PLoS 671 One. 2017;12(8):e0182801.

672 Senn S. Mastering variation: variance components and personalised medicine. Stat Med $673 \quad 2016 ; 35: 966-77$.

674 Shiiya T, Nakazato M, Mizuta M, Date Y, Mondal MS, Tanaka M, et al. Plasma ghrelin levels 675 in lean and obese humans and the effect of glucose on ghrelin secretion. J Clin Endocrinol Metab. $676 \quad 2002 ; 87(1): 240-4$.

677 Siri WE. Body composition from fluid space and density. In Brozek J \& Hanschel A (Eds.), 678 Techniques for measuring body composition. 1961;223-44. Washington, DC: National Academy 679 of Science.

680 Sonestedt E, Roos C, Gullberg B, Ericson U, Wirfält E, Orho-Melander M. Fat and carbohydrate 681 intake modify the association between genetic variation in the FTO genotype and obesity. Am J 682 Clin Nutr. 2009;90(5):1418-25.

683 Sondergaard E, Gormsen LC, Nellemann B, Vestergaard ET, Christiansen JS, Nielsen S. 684 Visceral fat mass is a strong predictor of circulating ghrelin levels in premenopausal women. 685 Eur J Endocrinol. 2009;160(3):375-9.

686 Speakman JR. The 'fat mass and obesity related' (FTO) gene: mechanisms of impact on obesity 687 and energy balance. Curr Obes Rep. 2015;4(1):73-91. 
688 Speakman JR, Rance KA, Johnstone AM. Polymorphisms of the FTO gene are associated with 689 variation in energy intake, but not energy expenditure. Obesity. 2008;16(8):1961-5.

690 Steiger JH. Beyond the F test: Effect size confidence intervals and tests of close fit in the analysis 691 of variance and contrast analysis. Psychol Methods. 2004;9(2):164-82

692 Stubbs RJ, Hughes DA, Johnstone AM, Rowley E, Reid C, Elia M, et al. The use of visual 693 analogue scales to assess motivation to eat in human subjects: a review of their reliability and 694 validity with an evaluation of new hand-held computerized systems for temporal tracking of 695 appetite ratings. Br J Nutr. 2000;84: 405-15.

696 Tschöp M, Weyer C, Tataranni PA, Devanarayan V, Ravussin E, Heiman ML. Circulating 697 ghrelin levels are decreased in human obesity. Diabetes. 2001;50(4):707-9.

698 Yoshimoto A, Mori K, Sugawara A, Mukoyama M, Yahata K, Suganami T, et al. Plasma ghrelin 699 and desacyl ghrelin concentrations in renal failure. J Am Soc Nephrol 2002;13(11):2748-52.

700 Weise CM, Hohenadel MG, Krakoff J, Votruba SB. Body composition and energy expenditure 701 predict ad-libitum food and macronutrient intake in humans. Int J Obes. 2014;38(2):243-51.

702 West J, Dahlqvist Leinhard O, Romu T, Collins R, Garratt S, Bell JD, et al. Feasibility of MR703 based body composition analysis in large scale population studies. PLoS 704 One. 2016;11(9):e0163332.

705 Whittingham MJ, Stephens PA, Bradbury RB, Freckleton RP. Why do we still use stepwise 706 modelling in ecology and behaviour? J Anim Ecol. 2006;75(5):1182-9. 